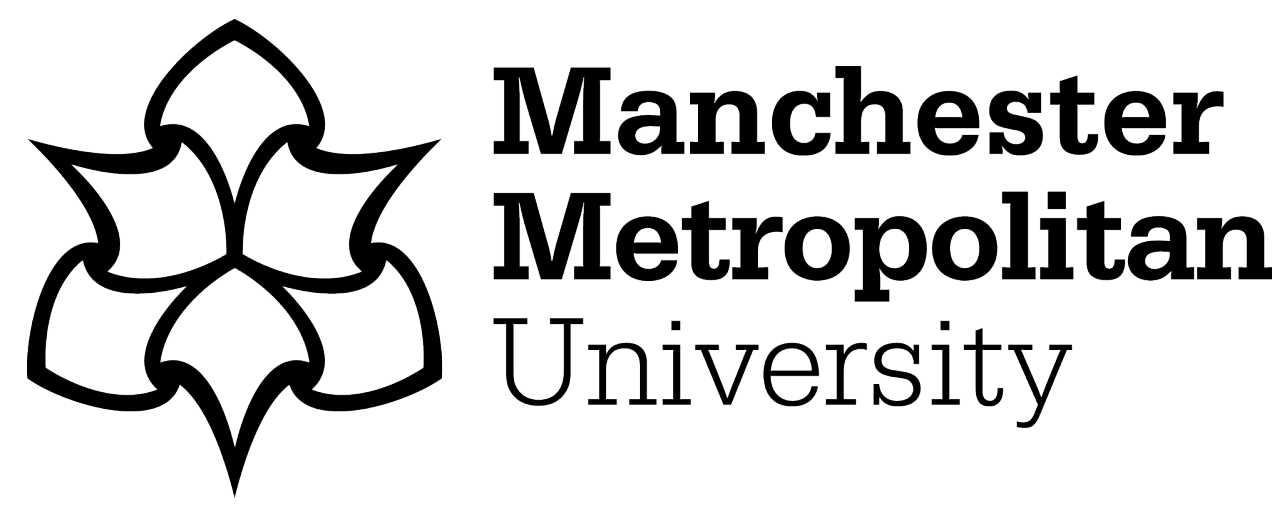

Najafi-Tavani, Z, Mousavi, S, Zaefarian, G and Naudé, P (2020) Relationship learning and international customer involvement in new product design: The moderating roles of customer dependence and cultural distance. Journal of Business Research, 120. pp. 42-58. ISSN 0148-2963

Downloaded from: https://e-space.mmu.ac.uk/626390/

Version: Accepted Version

Publisher: Elsevier

DOI: https://doi.org/10.1016/j.jbusres.2020.07.020

Please cite the published version 


\title{
Relationship Learning and International Customer Involvement in New Product Design: The Moderating Roles of Customer Dependence and Cultural Distance
}

\author{
Zhaleh Najafi-Tavani ${ }^{\mathrm{a}}$, Sahar Mousavi*1b ${ }^{\text {, Ghasem Zaefarian }}{ }^{\mathrm{a}}$, Peter Naudéc \\ ${ }^{a}$ Leeds University Business School, University of Leeds, United Kingdom \\ ${ }^{\mathrm{b}}$ School of Business and Economics, Loughborough University, United Kingdom \\ ${ }^{\mathrm{c}}$ Manchester Metropolitan University Business School, Manchester Metropolitan University, United \\ Kingdom
}

\begin{abstract}
This study focuses on relationship learning and its implications for international customer involvement during the design stage of the new product development (NPD) process. It utilizes relationship learning capability perspective to investigate the linkages between relationship learning, international customer involvement, and suppliers' performance. We also investigate whether customer dependence and cultural distance moderate the association between (a) relationship learning and international customer involvement and (b) international customer involvement and supplier performance. Using 264 respondents from Chinese manufacturing firms that have international customers, this study identifies that international customer involvement partially mediates the link between relationship learning and supplier performance. Furthermore, customer dependence strengthens, and cultural distance weakens, the effect of relationship learning on international customer involvement. However, only cultural distance negatively moderates the relationship between international customer involvement and supplier performance.
\end{abstract}

Keywords: international customer involvement, new product development, relationship learning, supplier performance, customer dependence, cultural distance.

\footnotetext{
$1 *$ Corresponding author: Email: S.Mousavi@1boro.ac.uk
} 


\section{INTRODUCTION}

Current business research and practice increasingly recognize the crucial role of involving customers in designing and developing superior products (Bendig, Enke, Thieme, \& Brettel, 2018; Cui \& Wu, 2016; Griffith \& Lee, 2016). Customer involvement includes supplierinitiated activities with the purpose of acquiring customer information, feedback, and knowledge to (co-)develop new products or improve existing ones (Menguc, Auh, \& Yannopoulos, 2014). At the international level, in addition to the significant cost of directly conducting market research in a foreign market, cultural and linguistic differences limit suppliers' ability to understand accurately export markets' preferences (Choi \& Contractor, 2016; Jean, Sinkovics, \& Hiebaum, 2014). For this reason, and to remain competitive, many firms increasingly involve their international customers in new product development (NPD) processes (Zhang, Zhong, \& Makino, 2015). As an example, Hilti Corporation, a global manufacturer of construction tools headquartered in Schaan, Liechtenstein, works closely with its international and local customers to develop new products that respond better to diverse needs of global markets (Cui \& Wu, 2017).

Despite the great scholarly attention that has been devoted to customer involvement, a number of important research gaps remain. First, design is a crucial stage in the NPD process which has direct implications for firms' new product success (Moultrie, Clarkson \& Probert, 2007). By involving customers in the design process, firms can offer tailored solutions that meet customers' unique needs and preempt product failures (Luchs, Swan \& Creusen, 2016). To date, very few studies have dealt exclusively with customer involvement at this stage (Menguc et al., 2014), especially at the international level. Such a practice would help suppliers better identify new product ideas, which creates additional value for those international customers (Griffith \& Lee, 2016). 
Second, existing studies on drivers/antecedents of customer involvement in the NPD processes are predominantly limited to scrutinizing the role of organizational related factors such as technical innovation capability, process and output control, and strategic flexibility and/or the role of market related factors such as competitor orientation, market ambiguity, and customer need heterogeneity (e.g., Cui \& Wu, 2016; Svendsen, Haugland, Grønhaug, \& Hammervoll, 2011; Zhang et al., 2015). Only scant attention has been paid to the relational capabilities needed to facilitate customer involvement (e.g., Mahr, Lievens, \& Blazevic, 2014). Nonetheless, recent contributions to supply chain and business marketing literature have emphasized the importance of relational capabilities such as relationship learning as mechanisms to enhance the effectiveness of governing customer-supplier exchanges (Chen, Lin, \& Chang, 2009; Cheung, Myers, \& Mentzer, 2011; Kohtamäki \& Partanen, 2016).

For instance, Lai et al. (2009) and Ling-Yee (2006) demonstrate that relationship learning enhances interfirm relationship performance. Similarly, Huikkola et al. (2013) find a positive association between joint (i.e. relationship) learning and R\&D services provided, and Kohtamäki \& Partanen (2016) found that relationship learning is critically important in value co-creation from supplier's offerings. In all these studies, relationship learning involves the frequent exchange of knowledge, which is then jointly interpreted and integrated in a shared relationship domain-specific memory (Selnes and Sallis 2003). While these studies point to the important implications that relationship learning holds for interfirm exchanges, to our best knowledge, no empirical study has yet examined the association between relationship learning and international customer involvement in the NPD processes. We argue that such learning mechanisms can enhance a firm's understanding of international customer's knowledgeability and attitudes towards collaboration, and subsequently impact the firm's willingness to engage a particular customer in new product design. 
Third, little consensus exists regarding the performance implications of customer involvement for suppliers. Whereas some studies have found that customer involvement has a positive impact on supplier's innovation performance (Chatterji \& Fabrizio, 2014), interfirm relationship profitability (Svendsen et al., 2011), and internationalization performance (Zhang et al., 2015), others did not find any effect on sales performance (Carbonell, RodríguezEscudero, \& Pujari, 2009), or even found negative impact on supplier performance (AnningDorson, 2018), supplier innovative performance (Knudsen, 2007), and human capital (Skaggs $\&$ Youndt, 2004). These inconsistencies are typically attributed to the lack of attention to factors that condition the consequences of customer involvement (Chatterji \& Fabrizio, 2014).

These highlighted gaps demonstate that our existing knowledge is insufficient for providing theoretically sound and managerially useful recommendations regarding whether, and under what conditions, relationship learning leads to more effective international customer involvement during design stage of the NPD process and what are the performance implications of such arrangements. Given that suppliers are becoming more reliant on their international customers to help with the development of new products (Griffith \& Lee, 2016; Menguc et al., 2014), we focus in our study on the role of customer dependence and cultural distance as two critical factors that could condition the effectiveness of international customer involvement.

Against this backdrop, the current study addresses the following research questions: (1) does international customer involvement during the NPD design stage mediate the link between relationship learning and supplier performance? and (2) whether and how cultural distance and customer dependency condition the effects of (a) relationship learning on international customer involvement and (b) international customer involvement on supplier performance. In doing so, we conducted our study in the context of Chinese manufacturing firms and their international customers. The geographic separation is best to capture the role of cultural distances on the matter in hand. 
This study makes three important contributions. First, our study integrates the customer involvement literature with organizational learning perspective and adopts the relationship learning perspective (Albort-Morant, Leal-Millán, \& Cepeda-Carrión, 2016; Cheung et al., 2011). This study, hence, answers recent scholarly calls (e.g., West, Salter, Vanhaverbeke, \& Chesbrough, 2014) to link customer involvement with established perspectives. Our results indicate that relationship learning as an interfirm capability is an important facilitator of international customer involvement in NPD processes without which suppliers will not be able to make best use of their international customers.

Second, we go beyond assuming that relationship learning always facilitates international customer involvement by empirically scrutinizing the contingent effects of both customer dependence and cultural distance that condition the effectiveness of relationship learning on customer involvement. Our results indicate that suppliers can benefit more from relationship learning capabilities when they share a similar culture and when the level of customer dependence is high. These findings signify that strategic decisions regarding developing and maintaining interfirm relational capabilities should be in line with contextual factors such as cultural distance and customer dependence.

Third, our study advances the business literature on international customer involvement, specifically at the "fuzzy" front-end design stage (Menguc et al., 2014) by further examining the impact of customer dependence and cultural distance on customer involvementsupplier performance link. In doing so, we address earlier calls (e.g., Chang \& Taylor, 2016) to examine the conditions under which customer involvement is beneficial to a focal supplier. Our results suggest that while customer dependence has no effect, cultural distance significantly decreases the effectiveness of international customer involvement on supplier performance. These findings are further explained in the discussion section. 


\section{Literature Review}

\subsection{Theoretical Background}

Superior product design capability has become critical to companies' sales growth and performance (Luchs, Swan, \& Creusen, 2016; Ulrich, 2011). Design contributes to improved product value offerings by boosting product quality and user interface experience (Menguc et al., 2014). It has been argued that customer-oriented design increases the NPD performance (Veryzer \& Borja de Mozota, 2005). Involvement of international customers at the design stage becomes even more important for NPD and hence suppliers' performance considering their lack of foreign market knowledge and experience (Zhang et al., 2015). The feedback, information, and knowledge provided by international customers substantially assist suppliers to overcome such liabilities of foreignness (Smets, Langerak, \& Rijsdijk, 2013). Consequently, by involving international customers, suppliers can offer tailored solutions that better meet an individual customer's unique needs, which ultimately reduces the risk of product failure (cf: La Rocca, Moscatelli, Perna, \& Snehota, 2016). Despite the importance of the design stage in the NPD process, few studies have dealt exclusively with customer involvement — especially of international customers - at this stage (Menguc et al., 2014).

This study, therefor, focuses on international customer involvement at the design stage of NPD project. While the importance of customer involvement has been acknowledged in the literature, very limited attention has been given to the relational capabilities that can encourage customer involvement (see table 1). Therefore, we propose that while having access to strategic resources is important to gain competitive advantage, suppliers need to possess capabilities to utilize such resources effectively (Newbert, 2007). By that rationale and following an organizational learning perspective (Fang, Fang, Chou, Yang, \& Tsai, 2011; Huikkola et al., 2013), we argue that the involvement of international customers in new product design provides opportunities for suppliers to access foreign-market knowledge, but that in order to 
realize such potentials, the exchange partners should first have the relationship learning capability in place. Following Selnes and Sallis (2003, p.80), relationship learning is " $a$ joint activity between a supplier and a buyer in which the two parties share information, which is then jointly interpreted and integrated into a shared relationship-domain-specific memory that changes the range or likelihood of potential relationship-domain-specific behavior". Insert Table 1 about Here

Earlier contributions have emphasized the importance of relationship learning as a way to decrease the risks inherent in international collaborations and as a mechanism to enhance the effectiveness of governing international customer-supplier relationships (Bendig et al., 2018; Chen et al., 2009; Jean, Kim, \& Bello, 2017). Relationship learning creates collaborative advantages for channel partners (Huikkola et al., 2013) by facilitating interfirm exchange of detailed information and, hence, enhancing a supplier's ability to understand and respond to partners' needs (Cheung, Myers, \& Mentzer, 2010). Possessing relationship learning capabilities yields appropriate learning mechanisms (Albort-Morant et al., 2016) that explain heterogeneity in outcomes of inter-firm relationships (Cheung et al., 2010, 2011; Selnes \& Sallis, 2003). Such learning mechanisms can enhance a potential supplier's understanding regarding international customer knowledgeability and attitudes towards collaboration before involving customers in the design stage of NPD (Chen et al., 2009). With this level of understanding, relationship learning not only affects a supplier's willingness to involve a particular international customer, but also serves as a buffer against the risk of involving unsuitable and unqualified customers in a NPD project. This study, therefore, assesses the association between relationship learning and international customer involvement and determines whether such an association ultimately improves suppliers' performance (see Figure 1). 
Drawing on capability related research in general (Narver, Slater, \& MacLachlan, 2004) and relationship learning in particular (Jean et al., 2017), we also anticipate that the association between relationship learning and international customer involvement, and their impact on supplier performance, are likely to be contingent on the contextual factors such as level of cultural distance and customer dependency. Cultural distance may distort communication between a focal supplier and its customers, thereby decreasing the firm's motivation and ability to identify and utilize the customer's competencies (Elia, Messeni Petruzzelli, \& Piscitello, 2019; Gu, Wang, \& Wang, 2019; Johnston, Khalil, Jain, \& Cheng, 2012). In contrast, customer dependency increases harmony and decreases the possibility of opportunistic behavior in an inter-firm relationship (Barnes, Leonidou, Siu, \& Leonidou, 2010), which in turn has been shown to increase the motivation and commitment of channel partners both before and during cooperation (e.g., Scheer, Miao, \& Garrett, 2010; Yeniyurt, Henke, \& Yalcinkaya, 2014). These two factors (i.e. cultural distance and customer dependency) have constantly been the focus of business and marketing scholars on relationship learning and international customer collaboration (e.g., Hewett \& Krasnikov, 2016; Jean et al., 2017; Johnston et al., 2012). Insert Figure 1 about Here

\subsection{Hypothesis Development}

When firms are involved in international cooperation, they must make significant investment in human and location assets, which mostly turn into sunk costs in the case of relationship termination (Zaefarian, Forkmann, Mitręga, \& Henneberg, 2017; Mitręga, Forkmann, Zaefarian, \& Henneberg, 2017). An increase in the retrospective costs of relationship termination and lack of commitment escalates the likelihood that exchange partners engage in opportunistic behaviors, thereby enhancing the perceived risk of involvement in international collaborations (Gençtürk \& Aulakh, 2007, Shiu, Jiang, \& Zaefarian, 2014). In other words, a supplier may question the motives and/or be suspicious 
about specific behaviors of the international customer and therefore be less willing to involve the international customer in product design. As both channel partners get involved in forming and sustaining the business relationship, the process of learning from that relationship begins, and with time, they begin to develop positive feelings towards their exchange partner, where they value the relationship, feel more comfortable with their exchange partner, and believe that their mutual needs are addressed (Cheung et al., 2010; Huikkola et al., 2013).

Moreover, relationship learning involves frequent exchanges of information and joint sense making activities (Selnes \& Sallis, 2003), and provides opportunities for a customer to communicate their motives and clarify misunderstandings with a supplier, This can not only improve customer's experiences in their relationship with the supplier and so their satisfaction and loyalty (Kohtamäki \& Partanen, 2016), but also it would earn the supplier's trust in and satisfaction with the relationship (Johnston et al., 2012). In addition, increased frequency of interaction (Jean, Sinkovics, \& Kim, 2010) with the customer enhances the supplier's ability to understand the value and relatedness of the international customer's resources (cf: Menguc et al., 2014), and become more willing to involve their customers in co-creation activities. Consequently, we believe that as the level of relationship learning increases, suppliers to become more willing to involve their customers in the design processes.

The results of earlier studies on product design indicate that customer involvement in NPD processes boosts supplier performance (Anning-Dorson, 2018) through enhancing the performance of new products (e.g., Lau, Tang, \& Yam, 2010). The incentive for involving customers in the design process is so that a supplier can exploit a customer's tangible and intangible resources (including product-market knowledge) that the supplier may lack internally (Menguc et al., 2014). International customer involvement enables the supplier's design team to anticipate a product's potential problems earlier and take appropriate actions in rectifying those issues (Fang, 2008). Moreover, by using customer's know-how, suppliers can 
more accurately filter and choose promising ideas more efficiently, since through co-creation activities, customers can provide feedback on design ideas (Chang \& Taylor, 2016). In this way, by involving international customers in the design process, the focal supplier develops a better understanding of market needs which should then result in the development of betterperforming new products with an enhanced products-market fit (Carbonell et al., 2009). Thus, in line with previous studies, we believe that customer involvement in NPD processes can increase supplier performance. Taken together, we hypothesize that:

Hypothesis 1: International customer involvement in product design mediates the positive relationship between relationship learning and supplier performance.

Dealing with culturally distant exchange partners is one of the key challenges in international collaborations (Hewett \& Krasnikov, 2016; McGrath \& O'Toole, 2014). Cultural distance refers to the degree of divergence between the cultural norms and values of the exchange partners from distinct geographical regions (Sousa \& Bradley, 2006). As mentioned earlier, relationship learning increases international customer involvement by easing the exchange of knowledge and information between suppliers and customers (Chen et al., 2009). However, cultural differences can hinder if not distort the process of learning from the relationship. It is a company's unique capability to perform effectively in situations characterized by cultural diversity (Najafi-Tavani et al., 2018). By contrast, partners from culturally similar backgrounds can more readily understand each other since they often share a common point of reference (McGrath \& O'Toole, 2014). The cognitive awareness of differences among two cultures enable partners to develop a better understanding of each other and their expectations. Such a cognitive awareness of cultural differences can therefore lead to motivational and behavioral aspects of cultural intelligence.

Relationship learning facilitates the exchange of information and encourages suppliers to overcome uncertainty and involve their customers in co-creation activities (Selnes \& Sallis, 
2003). If cultural distance is low, there is more common ground to share knowledge. Therefore, the supplier is able to more readily recognize the relatedness and value of such a customer's knowledge. This, in turn, enhances suppliers' willingness to involve customers more in cocreation activities. By contrast, a high level of cultural distance can impede the supplier's ability to understand the information exchanged through relationship learning, and thus underestimate a customer's competencies, which in turn demotivates a focal supplier from engaging their international customers in the design process.

Moreover, it has been argued that cultural distance can damage supplier-customer relationships through hindering or distorting communications (Rosenbloom \& Larsen, 2003). When the level of cultural distance is high, the supplier may misinterpret the customer's communication, which can increase the level of stress and conflict in a relationship (Johnston et al., 2012). Therefore, through relationship learning, a supplier may identify customer competencies that can benefit product design, but because of their cross-cultural differences and subsequent conflicts and uncertainties, it may be reluctant to involve the customer. This is particularly the case when the cost of interpreting partners motives and behavioral intentions is high. Conversely, when suppliers and customers share similar cultural values, they can better understand their partners' behavior. Such understanding then decreases conflict and increases satisfaction and trust in the relationship (Leonidou, Samiee, Aykol, \& Talias, 2014). Therefore, while relationship learning augments the supplier's awareness regarding the value of customer knowledge, a low level of cultural distance reduces the conflict and perceived risk, resulting in a greater probability of the supplier involving the customer at the design stage.

Overall, cultural distance negatively affects the initial stage of involving customers in the design process by diminishing the link between relationship learning and international customer involvement. Because of dissimilarities, a supplier may become (a) less capable of 
identifying customers' competencies and (b) less willing to involve them at the design stage. We therefore suggest the following:

Hypothesis 2: A high level of cultural distance weakens the positive relationship between relationship learning and international customer involvement.

Lau et al., (2010) assert that firms must involve their customers in the design process to understand their complex needs, and to improve products and overall firm-performance. We, however, suggest that such a favorable outcome (i.e. consequences of involving the customer in design process) depends on context-related factors such as cultural distance that can influence the effectiveness of involving customers mainly in two distinct ways.

First, it has been shown that cultural distance diminishes the effectiveness of the twoway communication between channel partners (e.g., Elia et al., 2019; Rosenbloom \& Larsen, 2003; Schmitt \& Van Biesebroeck, 2013). Channel partners with a high level of cultural distance are more exposed to communication disruptions, and hence misinterpretation of customers' information, due to heterogeneity in values, approaches, and motivations (Lew, Sinkovics, Yamin, \& Khan, 2016). Moreover, the combination and coordination of resources — provided by customer involvement in NPD process - becomes more difficult for channel partners with diverse cultures as they are exposed to different psychological environments (Abdi \& Aulakh, 2012). As such, while involvement of an international customer in the NPD process may provide learning opportunities in terms of design ideas and solutions needed for the creation of superior products, cultural distance limits suppliers' ability to fully realize such potentials. In contrast, a lower cultural difference, or its absence, facilitates more meaningful two-way communication between suppliers and their international customers. When cultural differences are negligible, supply partners are better able to adjust their behaviors in ways that are more precisely in line with what is culturally acceptable by the partner. Consequently, a supplier will be in better position to exchange and link its current resources to those of the 
international customer, leading to enhanced supplier ability in developing new designs that meet market requirements.

Secondly, cultural distance can lead to decreased harmony (Leonidou, Katsikeas, \& Hadjimarcou, 2002) and heightens misunderstandings in interfirm exchanges, which ultimately decreases the positive association between international customer involvement and supplier performance. Once involved in design processes, customers and suppliers actively participate in joint problem-solving activities, enabling a supplier to develop new products that offer important benefits to customers (Griffith \& Lee, 2016). However, high cultural distance impedes joint actions, and hence limits the effectiveness of international customer involvement, by reducing partners' ability to understand each other's behaviors, generating a perception of opportunism and unfairness, and eroding trust and satisfaction in the interfirm relationship (Johnston et al., 2012; Katsikeas, Skarmeas, \& Bello, 2009). In contrast, cultural closeness facilitates joint problem-solving activities between a supplier and its international customer through fostering trust, facilitating relationship building, reducing misinterpretations, and eradicating ambiguities (Hewett \& Krasnikov, 2016; Johnston et al., 2012).

In sum, we posit that a high level of cultural distance reduces the benefits of international customer involvement by disrupting communication and distorting trust and harmony in interfirm exchanges. We therefore suggest:

Hypothesis 3: A high level of cultural distance weakens the positive relationship between international customer involvement and supplier's performance.

Customer dependence refers to the extent to which a customer needs to retain a relationship with a specific supplier to gain access to particular resources (Fang, Palmatier, \& Evans, 2008). The nature of customer dependency can be based on positive motives e.g. due to the inherent benefits associated with the core offering or operations capability of the supplier or based on negative motives e.g. switching costs (Scheer et al., 2010). Customer dependence however is 
more prevalent when replacing a supplier is difficult because of either high switching costs and/or a lack of suitable alternatives. The extent of customer dependence can strengthen the association between relationship learning and international customer involvement in two ways. First, without direct customer participation in sharing their knowledge and/or showcasing their competencies and capabilities, the supplier may easily overlook such opportunities to use the customer's unique set of skills that are often tacit and complex but vital for the supplier wishing to differentiate their product designs from those of competitors. In other words, the customer may well be resourceful and knowledgeable, but the supplier may well fail to realize the full potential of such a customer to contribute to the design process.

When the level of customer dependency is high, the customer becomes more motivated to form and maintain its business relationship with the supplier (Skarmeas, Katsikeas, \& Schlegelmilch, 2002), and thus becomes more interested in and committed to proactively assisting the supplier to identify and understand its competencies, for example through training and knowledge dissemination workshops. As a result, while relationship learning can enhance supplier awareness of explicit customer capabilities, without the customer's proactive role in showcasing its skills, such learning mechanisms may not be sufficient to fully comprehend customer capabilities. Conversely, if the level of customer dependency is low, the relationship becomes less important for customers and thus they may become less motivated, if not reluctant, to showcase their capabilities to the supplier. Under these circumstances, and through relationship learning, a supplier may merely recognize the customer's explicit rather than tacit competencies, in which case it reduces the supplier's willingness to involve international customers in co-creation activities.

Secondly, fostering cooperation between suppliers and international customers requires specific investments in the relationship, which increases the possibility (or at least the perception) of opportunistic behaviors (Jean et al., 2017). Therefore, while relationship 
learning facilitates suppliers' recognition of the customers' competencies that are useful to product design, due to the inherent risks of international cooperation, suppliers may refuse to involve their international customers in design processes. However, when the level of customer dependency is high, the supplier may become more confident in the customer's behavior and compliance, since it knows that the customer performance will suffer considerably if the relationship is terminated (Jap \& Ganesan, 2000).

Therefore, a high level of dependency assures a focal supplier that the international customer (identified through relationship learning) will not involve in opportunistic behavior, which in turn increases the possibility of engaging such a customer in design processes. In contrast, since a low level of customer dependency means that the customer can easily terminate the relationship (Barnes et al., 2010), the supplier becomes less certain of the customer's intentions. Under these circumstances, even though relationship learning can help a supplier to comprehend the potential contribution of a given customer in design processes, it may refuse to participate in co-creation activities with that customer due to uncertainty regarding the customer's commitment that stems from low levels of customer dependency. Therefore, the following is proposed:

Hypothesis 4: A high level of customer dependence strengthens the positive relationship between relationship learning and international customer involvement.

We also anticipate that customer dependency conditions the association between international customer involvement and supplier performance in two different ways. First, customer dependence has been consistently conceptualized as a predictor of commitment or loyalty i.e. in the form of relational or behavioral loyalty. Repeated episodes of quality interaction between a customer and its supplier result in a positive relationship between the two parties and the unique benefits received by the customer lead to higher relationship satisfaction, and therefore high relational and behavioral loyalty (Scheer et al., 2010). As customer dependency on the 
supplier increases, the opportunity cost of not contributing to co-creation activities increases (Yeniyurt et al., 2014). Consequently, in order to reduce its economic exposure, the customer becomes more willing to increase the depth and breadth of its interactions with the supplier that ultimately results in the creation of stronger orientation towards information sharing and cooperation (Kim \& Henderson, 2015).

Within the context of our study, this means that at high levels of customer dependency, the customer becomes more committed to assist the supplier in developing superior designs. A customer's willingness to become more closely involved in the co-development process is mainly due to inherent benefits associated with core offerings of the supplier (positive motivations) but also to restore the power balance and hence decrease its vulnerability (Gençtürk \& Aulakh, 2007). For this reason a highly dependent customer makes significant efforts to openly and frequently transferring information regarding product design architecture or the design requirement of the market with the aim to ultimately enjoy the long-term benefits (Yan \& Dooley, 2014). Conversely, when the level of dependency is low, the relationship becomes less important for the international customer as it can easily switch to other suppliers (Barnes et al., 2010). Considering the non-monetary and monetary costs of participating in codevelopment activities (Hoyer, Chandy, Dorotic, Krafft, \& Singh, 2010), the customer becomes even less committed and less willing to actively contribute to supplier NPD activities. Without customer commitment, co-creation activities with suppliers will not be fruitful and are more likely to result in suboptimal designs and lower supplier performance.

Secondly, from a supplier's perspective, a higher level of customer dependency reduces the perceived risk of customer opportunistic behavior. When involving customers in the design process, it is imperative that the focal supplier allocates critical resources to enhance the effectiveness of co-creation activities (Fang et al., 2008). Such investments are highly relationship specific, and thus incur high switching costs if the relationship is terminated (Heide 
\& John, 1988). When the level of customer dependency is low, the supplier may feel reluctant to further invest in co-innovation due to the possibility of customer opportunistic behavior (Gençtürk \& Aulakh, 2007). The supplier's uncertainty over the customer's behavior reduces the supplier's willingness to allocate those resources needed for the success of co-creation activities, thereby decreasing the effectiveness of international customer involvement in the design stage of the NPD. The resultant lack of supplier support potentially reduces the quality of co-creation, leading to less successful designs and, eventually, lower supplier performance. However, a higher level of international customer dependency increases the supplier's willingness to dedicate more resources during the process of co-creation, given that such dependency assures the supplier that the international customer is willing to sustain the relationship and will not engage in opportunism (Gao \& Shi, 2011). We, therefore, hypothesize the following:

Hypothesis 5: A high level of customer dependence strengthens the positive relationship between international customer involvement and supplier performance.

\section{Method}

\subsection{Context and Data Collection Procedures}

The research examines the relationship between suppliers in medium to large (i.e., those with more than fifty employees) manufacturing firms in China and their international customers. China was chosen for a number of reasons. First, it now has the world's biggest manufacturing economy, and over the past decade has become the largest exporter in the world (Statista, 2020). Secondly, in order to maintain their competitive advantage, China is actively attempting to improve their innovation record by pursuing international NPD opportunities (Bao, Chen, \& Zhou, 2012; Liu, Luo, \& Shi, 2003; Zhou, Tse, \& Li, 2006). They are doing this by learning 
from external parties to reduce the competency gap between Chinese firms and long-standing firms from developed countries (Atuahene-Gima, 2005). Finally, Chinese firms, when interacting with others, traditionally use social relationships (e.g., guanxi) (Zhou, Zhang, Sheng, Xie, \& Bao, 2014).

Our respondents were managers, which included CEOs, presidents, vice presidents, production managers, sales managers, and $R \& D$ managers who were directly involved in designing new products and who had direct involvement in the management of international customer relationships. We asked these respondents to select one of their leading international customers (top-five) by sales value (Zhou et al., 2014) with whom they had had a relationship for longer than twelve months (Wang, Bradford, Xu, \& Weitz, 2008).

In order to test our hypotheses, a cross-sectional online survey was developed. To validate the conceptual equivalence of our survey, the questionnaire was first developed in English, and then translated by independent translators into Chinese, before being translated back into English (Poppo \& Zhou, 2014). A group of five senior marketing managers were interviewed to check the content and face validity of the constructs (Poppo, Zhou, \& Li, 2016). The questionnaire was given to thirty senior managers for their feedback on wording and design in order to finalize the questionnaire (Zhou et al., 2014). We then sent the survey to a random selection of 1000 managers, incentivized by a market research firm. The data was collected during autumn 2017. We received a total of 264 responses from managers across different managerial grades and diverse industries. Table 2 illustrates the summary of the respondent profiles.

Insert Table 2 about Here

The firms had been established for an average of 14.5 years. The majority of the firms (75.1\%) had 100 to 500 employees, $17.1 \%$ had more than 500 employees, whilst $8 \%$ had less 
than 100 employees. Annual sales of these companies averaged $¥ 16.5$ billion, with R\&D investment an average of $¥ 306$ million. The respondents had been with their firms for an average of 9.3 years and had been in their present position for almost five years. The average length of the relationship surveyed was five years. The statistics show that the respondents had reliable knowledge about their firms and their international customers, indicating that the relationship between suppliers and their identified customers was meaningful (Larwood, Falbe, Kriger, \& Miesing, 1995; Wang et al., 2008). The respondents' knowledge about their firm's relationship with the selected customer and their level of confidence in answering the questionnaire were also assessed. We found that the respondents' knowledge level and confidence level on a scale from 1 to 7 (very low to very high) has means of 6.32 and 6.39 respectively.

\subsection{Variables and Measures}

Relationship learning was measured using the three sub-dimensions of information sharing, knowledge integration, and joint sense making adapted from Selnes and Sallis (2003). It refers to joint activities between the supplier and its customer, wherein the two parties share information, jointly interpret and make sense of information, and integrate acquired information into a shared relational memory that improve the range or likelihood of potential relationship-domain-specific behavior (Selnes \& Sallis, 2003). International customer involvement in the design stage was measured using items adapted from Menguc et al. (2014). It refers to the frequency of particular activities (e.g., cross-functional design teams with customers and reviewing designs by customers) where customers participate in supplierinitiated practices, providing information, feedback, and knowledge in order to ensure that customers' requirements are met in new product designs (Menguc et al., 2014). Supplier performance (adapted from Katsikeas, Samiee, \& Theodosiou, 2006) was measured using the 
three sub-dimensions of financial performance (in terms of profitability as a percentage of sales, return on investment, and profit growth), sales performance (assessing sales volume, sales growth, and new product sales), and customer performance (in terms of customer satisfaction, customer retention, and customer referral) in comparison to their main competitor. Customer dependence, the need to retain a relationship between the supplier and customer, was adapted from Fang et al. (2008). It evaluates the supplier's perceived dependence of the customer on them. The cultural distance between supplier (China) and international customer's country of origin was measured using the Kogut and Singh (1988) model based on Hofstede's (1980) four dimensions of culture. The cultural distance was calculated based on the deviation (corrected for differences in the variances) along the four cultural dimensions of each international customer's country from China's scores. The average of these deviations was calculated as follows:

$$
C D_{j}=\sum_{i=1}^{4}\left\{\left(D_{i j}-D_{i c}\right)^{2} / V_{i}\right\} c / 4
$$

Where $\mathrm{CD}_{\mathrm{j}}$ represents the cultural distance of the $j$ th country from China, $\mathrm{D}_{\mathrm{ij}}$ represents the index for the $i$ th dimension in $j$ th country, and $\mathrm{D}_{\mathrm{ic}}$ is the equivalent dimension for China.

Control variables: Heterogeneity was controlled at four different levels. First, relationship age and mutual relationship-specific investment (RSI) were considered as two exchange characteristics. Stable inter-firm relationships that come with age, thrive learning initiatives, and provide an environment for better and more effective engagement with longstanding suppliers (Jean, Kim, \& Sinkovics, 2012; Ryu, Park, \& Min, 2007). We measured relationship age as the number of years the two companies had been doing business with each other. The level of mutual RSI, which captures the level of investments made by both customer and the supplier dedicated to the relationship, may affect their performance (Palmatier, Dant, \& Grewal, 2007). 
Second, we controlled for six firm-level variables namely supplier size, supplier age, overseas market age, $R \& D$ expenditure, number of New Products Developed (NPD), and joint innovation activities. Typically, larger firms have greater power compared to smaller counterparts (Poppo \& Zhou, 2014). This power asymmetry exists because larger firms tend to have a greater resource base, which they can use to generate better synergies, leading in turn to increased performance (Jean et al., 2012). Therefore, we controlled for supplier size which was measured by number of employees categorized into seven groups starting from the smallest category 1, from 50 to 100 employees, to the largest category 7, greater than 500 employees. We also controlled for supplier age because older firms tend to have additional resources, knowledge, and capabilities accumulated over the duration of their existence (Lazzarini, Claro, \& Mesquita, 2008). However, older firms are more susceptible to organizational inertia, which makes them less innovative (Phelps, 2010). In addition, we controlled for the overseas market age by measuring the number of years that the supplier had operated in the international market to capture firm's experience for international presence, which can impact its performance (Brouthers, O'Donnell, \& Hadjimarcou, 2005). R\&D expenditure is typically an indication of how much a firm is focusing on new product development and often to certain extend can define or influence firm's performance (Cui \& Wu, 2016), hence we controlled for firm's yearly $R \& D$ expenditure in our model. For the same reason, we captured the firms' number of new products developed in the previous three years as a measure of the firm's experience with, and emphasis on NPD (Kuester, Homburg, \& Hildesheim, 2017). Finally, we controlled for joint innovation activities, which captured the degree of joint innovation efforts by both parties as an indication of how much the focal firm emphasizes on international customer involvement in design and learning through building relationships.

Third, adapting from Lavie et al. (2012), we controlled for customer's value proposition and customer's global reach to consider their likely influence on the supplier's performance. 
Customer's value proposition was measured in terms of: (1) knowledge about the firm's products and platforms, (2) efforts to promote these products and platforms, (3) ensuring quality of services, and (4) viability of their business model. Customer's global reach indicates the level of the customer's operations at regional, national, or global level.

Fourth, we captured and controlled for market conditions that could influence the supplier's performance (Lavie et al., 2012). Finally, the respondent's tenure (i.e., the number of years the respondent had been employed by the company) was controlled for possible respondents' effects (Zhou \& Li, 2012).

\section{Analyses and Results}

\subsection{Measurement Checks}

Common Method Bias Assessment: Since we collected our survey data through a single informant, we checked for the potential existence of common method bias (CMB). We ran the Harman single-factor test (Podsakoff, MacKenzie, Lee, \& Podsakoff, 2003) which loads all the items into an exploratory factor analysis. Factor one explained 30.3\% of the variance, indicating that $\mathrm{CMB}$ is not a substantial issue in this study. We also employed Lindell and Whitney's (2001) method variance (MV) marker variable analysis. We used the company's attention to their management (a four-item scale with Cronbach's $\alpha$ of 0.710 and mean score of 5.13) as the marker variable, since it was theoretically unrelated to the main constructs in the model. The adjustment of the correlations among constructs and statistical significance for the smallest positive correlation between the marker variable and others $(r=0.01)$, revealed that the pattern of significant and insignificant correlations maintained the same, indicating that CMB is not a concern in our study.

Measurement Model Assessment: We used AMOS 22.0 to perform a confirmatory factor analysis (maximum likelihood estimation) with all eight first-order factors in our model. 
The measurement model fit was satisfactory $\left(\chi_{(d f=467)}^{2}=721.03 ; \mathrm{CFI}=0.95\right.$; IFI=0.95; TLI= 0.94; RMSEA=0.04) and all items factor loadings were over $0.65(p<0.01)$. All composite reliabilities and Cronbach's alphas exceeded 0.79 (Appendix 1) and average variance extracted (AVE) measures were over 0.52. Moreover, the square root of the AVE for each construct exceeded the correlation estimate between all pairs involving that construct and other constructs (Table 3 ).

We also performed pairwise chi-square difference tests twice for the research model constructs. First, the $f$ coefficient was set to be free (model 1), and then it was constrained to unity (model 2). The $\Delta X^{2}$ between all pairs confirmed that model 1 is better than the model 2 at a significant level, $p<0.01$. These results confirm the discriminant validity of the measurement model. Table 3 illustrates the correlations and descriptive statistics for the model constructs.

\section{Insert Table 3 about Here}

Endogeneity Assessment: our analysis and therefore the findings of the consequences of relationship learning might be misleading because of endogeneity bias, given that relationship learning is a variable that is not randomly assigned across our sample (that is, managers could choose the extent to which they learn from relationships, i.e., how much they share, make sense of, and integrate information and knowledge) (Zaefarian, Kadile, Henneberg, \& Leischnig, 2017). We used the control function approach (Petrin \& Train, 2010) to assess whether our analysis was subject to self-selection bias. Such a procedure has received support in the marketing literature (e.g., Wang, Lee, Fang, \& Ma, 2017). In this approach, the residuals for our predictor are obtained through regressing the relationship learning on the selected instrumental variable (i.e. supplier size), the moderating variables (i.e. customer dependence and cultural distance), and all control variables. The instrumental variable should affect the endogenous variable, i.e., relationship learning but should not be related to the 
customer involvement as the dependent variable (Ullah, Zaefarian, \& Ullah, 2020). We used supplier size as the instrumental variable because relationship learning is generally greater in larger firms. However, we found no evidence that the size of a firm affects the customers' involvement at the design stage of the NPD. We use Eq1 to predict the residuals:

Eq1: $\mathrm{RL}=\alpha_{0}+\alpha_{1} \mathrm{CDep}+\alpha_{2} \mathrm{CDis}+\alpha_{3} \mathrm{SS}+$ Controls $+\zeta$

Wherein RL refers to relationship earning, CDep refers to customer dependence, CDis refers to cultural distance, and SS refers to supplier size. The results from the first stage model suggest that supplier size is positively related to relationship learning $\left(\alpha_{3}=0.12, p<0.05\right)$, indicating satisfactory instrument strength. In the second stage, we use the predicted residuals as a control variable to address the self-selection bias using Eq2.

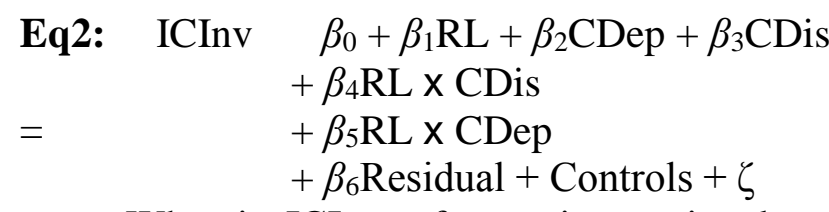

Wherein ICInv refers to international customer involvement in the design stage. In order to examine whether our analyses are subject to self-selection bias, we compared our results in Eq2 with the rival model (Eq3) wherein the residuals obtained from Eq1 were not included in the model:

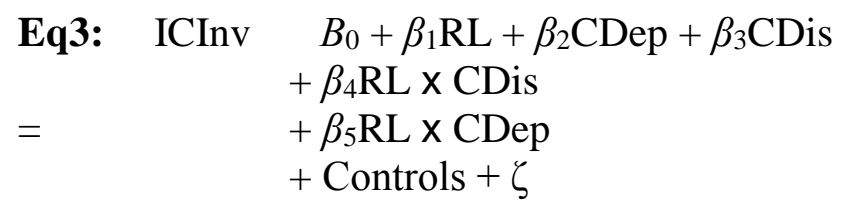

Comparison of our results from Eq2 and Eq3 (see Table 4) suggest that the overall pattern of significance remained the same, confirming that our analyses are not affected by self-selection bias.

Insert Table 4 about Here 


\subsection{Structural Model Results}

We draw on structural equation modelling approach to examine our hypotheses. Lower order variables were represented in the model by their indicators. Sub-dimensions of relationship learning and those of supplier performance were aggregated to create corresponding first-order factors. In doing so, we took the arithmetic average of the scores of items for each secondorder construct into an aggregate score. The standardized factor loadings of the three first-order factors of information-sharing, joint-sensemaking, and knowledge-integration for the secondorder factor of relationship learning were significant and well above the cut-off point of 0.7 (information sharing $=0.71$; joint sensemaking $=0.82$; knowledge integration $=0.91$ ) as were the standardized loadings for the second-order factors of the supplier performance (sales performance $=0.90$; financial performance $=0.83$; customer performance $=0.84$ ). Thus, in our structural model, both relationship learning and supplier performance were treated as firstorder constructs with three aggregated items.

We also created four interaction terms, i.e., Relationship Learning x Cultural Distance, Relationship Learning $\mathrm{x}$ Customer Dependence, International Customer Involvement $\mathrm{x}$ Cultural Distance, and International Customer Involvement x Customer Dependence, which were added to our structural model in line with the suggestion of Ping (1995). We meancentered these constructs before creating the interaction terms, given that product terms can incur collinearity (Aiken, West, \& Reno, 1991).

We estimated the structural model in AMOS 22.0 with the maximum likelihood method for estimation. We obtained good fit for the structural model: $X_{(d f=322)}^{2}=488.93$; RMSEA= 0.05; $\mathrm{CFI}=0.92 ; \mathrm{TLI}=0.90$. Table 5 provides the standardized path coefficients $(\mathrm{SPC})$ for all relationships in the structural model and the control variables. We also report the $95 \%$ confidence intervals for the direct effects in this table. These confidence intervals were generated from bootstrapped procedure in AMOS with 1000 samples. 
To examine the mediation effect for $\mathrm{H}_{1}$, we ran a full mediation model in which international customer involvement fully mediates the effects of relationship learning on supplier performance. As expected, the path from relationship learning to international customer involvement was positive and significant $(\mathrm{SPC}=0.36, p<0.01)$. Similarly, the path from international customer involvement to supplier performance was significant $(\mathrm{SPC}=0.24$, $p<0.01)$. To better understand the mediating role of international customer involvement, we compared these results against a rival model of partial mediation in which we included a direct link from relationship learning to supplier performance in addition to the effects mediated through international customer involvement. The result for the partial mediation model is also provided in Table 5. The partial mediation model obtained slightly better fit: $\mathrm{X}_{(d f=321)}^{2}=467.39$; RMSEA $=0.05 ; \mathrm{CFI}=0.93 ; \mathrm{TLI}=0.91$. The addition of this direct link from relationship learning to supplier performance significantly improved the model $\left(\Delta X_{d f=1}^{2}=21.54, p<0.01\right)$. The direct link between relationship learning and supplier performance was significant (SPC= $0.38, p<0.01)$ as were the paths from relationship learning to international customer involvement $(\mathrm{SPC}=0.35, p<0.01)$ and from international customer involvement to supplier performance $(\mathrm{SPC}=0.15, p<0.05)$. These results indicate that international customer involvement partially mediates the path from relationship learning to supplier performance.

As illustrated in Table 5, the standardized path coefficient for the interaction term Relationship Learning x Cultural Distance is negative and significant in both models (SPC = $0.18, p<0.01$ in both models), providing support for the second hypothesis. In hypothesis 3 , we proposed that cultural distance negatively moderates the path from international customer involvement to supplier performance. This hypothesis is also supported, given that the standardized beta coefficient is negative and significant $(\mathrm{SPC}=-0.22, p<0.01$ for the full mediation model and SPC $=-0.19, p<0.01$ in the partial mediation model). Hypothesis 4 suggested that customer dependence positively moderates the effect of relationship learning on 
international customer involvement. We found support for this hypothesis: the standardized path coefficient for the interaction term Relationship Learning x Customer Dependence is positive and significant $(\mathrm{SPC}=0.14, p<0.05$ in both models). However, customer dependence does not moderate the positive effect of international customer involvement on supplier performance, hence rejecting $\mathrm{H}_{5}$.

Insert Table 5 about Here

We further tested the direct relationships in our model for potential non-linearity effect as an alternative explanation. We run three different regression tests to check for potential existence of curvilinear effect in (1) the path from relationship learning to international customer involvement, (2) the path from international customer involvement to supplier performance, and (3) the path from relationship learning to supplier performance. We included both our moderators and all the control variables in all these regressions models. We also meancentered our predictor construct before creating the quadratic term.

As for the first model (i.e. relationship learning to international customer involvement), path coefficient for the quadratic term $\left(\mathrm{RL}^{2}\right)$ was -0.012 ( $\mathrm{t}=-0.161$, not significant). In the second model (i.e. international customer involvement to supplier performance), path coefficient for the quadratic term $\left(\mathrm{ICInv}^{2}\right)$ was also negative but not significant $-0.063(\mathrm{t}=-$ 0.973). In the third model (i.e. relationship learning to supplier performance), the quadratic term $\mathrm{RL}^{2}$ was not significant $(\mathrm{B}=-0.006, \mathrm{t}=-0.078)$. Hence, we can safely conclude that the relationships between the main constructs are linear.

\section{DISCUSSION}

The importance of customer involvement in NPD has been widely recognized in the literature, however there are very few studies that examine how and under what conditions relational capabilities such as relationship learning facilitates such activities. Moreover, relatively little 
attention has been devoted to the effectiveness of customer involvement during the design stage of NPD, particularly at international level in customer-supplier relationships. The aim of this study is to answer two questions: first, whether the international customer involvement mediates the association between relationship learning and supplier performance. Second, whether and how cultural distance and customer dependency condition the link between (a) relationship learning on international customer involvement and (b) international customer involvement on supplier performance. Our results indicate that international customer involvement only partially mediates the association between relationship learning and supplier performance given that relationship learning can directly increase supplier performance. Regarding the second research question, cultural distance decreases the effectiveness of both relationship learning and international customer involvement, while customer dependency conditions only the effectiveness of relationship learning.

\subsection{Theoretical Contributions}

This study contributes to the existing literature on customer involvement in NPD processes in three ways. First, this study contributes to theoretical development by being the first to examine the effects of relationship learning on international customer involvement. In doing so, this study addresses the earlier calls for using established perspectives in examining customer involvement (West et al., 2014). Our results reinforce the conventional view that emphasizes the key role played by relational investment in generating a platform necessary for success of interfirm collaborations (Chen et al., 2009; Huikkola et al., 2013; Jean et al., 2017). Relationship learning enhances the supplier's willingness to involve its international customer in development of new designs by not only decreasing the perceived risk of engaging in such activities (e.g. opportunistic behavior), but also enhancing the supplier's ability to more precisely evaluate the value of customers' ideas and knowledge. Along with the work of Jean et al. (2017) and Huikkola et al. (2013), our research points to relationship learning as an 
effective theoretical perspective in developing an understanding of international customer involvement as a joint learning process and not just as an outcome of firm knowledge management processes, channel partners' slack resources, or environmental attributes.

The second contribution of this study is to demonstrate that the effectiveness of relationship learning rests upon contextual factors governing the international interfirm relationships. In particular, our findings indicate that cultural distance decreases the effectiveness of relationship learning. The identified novel contingent effect is in line with an emerging line of enquiry on the role of cultural distance in interfirm collaborations (Cheung et al., 2011; Elia et al., 2019). A high level of cultural distance can create misunderstanding and conflict between channel partners (Katsikeas et al., 2009) which ultimately discourages a supplier from involving its international customers in development of new product designs. Our results also demonstrate the need to include customer dependence when examining effectiveness of relationship learning. Despite the presumed importance of customer dependence on marketing channels' attitude and orientation towards engaging in interfirm collaborations (Gao \& Shi, 2011; Kim \& Henderson, 2015), there exist no empirical investigation of how customer dependence conditions the relationship learning - customer involvement link. Our research addresses this gap by empirically investigating and demonstrating the moderating effects of customer dependence on effectiveness of relationship learning. Overall, our findings challenge the conventional belief that the relationship learning always enhances interfirm collaborations (e.g., Chen et al., 2009; Cheung et al., 2010), and suggest a need for careful considerations of contextual factors such as cultural distance and customer dependence when examining the consequences of relationship learning.

Third, while a number of earlier studies (e.g., Morgan, Obal, \& Anokhin, 2018; Zhang et al., 2015) point to the importance of involving international customers in NPD processes, they paid little attention to how cultural distance, as an important boundary condition in 
international exchanges, challenges the effectiveness of such activities. We address this limitation by being the first to check the conditioning effect of cultural distance on success of international customer involvement. The rationale is that cultural distance impedes supplier ability to acquire and correctly interpret customer's knowledge regarding market needs by disturbing communications (Schmitt \& Van Biesebroeck, 2013) and decreasing the harmony in interfirm relationships (Leonidou et al., 2002), thereby lessening the benefits of involving customers in development of new designs. Our findings demonstrate that the supplier's ability to benefit from international customer involvement in design stage of NPD project significantly depends on the cultural distance between channel partners. As such the moderating role of cultural distance can explain the inconsistencies in literature regarding the consequences of customer involvement.

Opposite to our expectations, our findings did not support the moderating role of customer dependency in the relationship between international customer involvement and supplier performance. Increased supplier dependency on international customer involvement may explain this result. When suppliers involve their international customers in co-creation activities, they should make RSIs that have no value outside of the relationship itself (Fang et al., 2008). Consequently, such arrangements increase suppliers' dependency on their international customers by increasing the switching costs in the event of relationship termination (Heide \& John, 1988). Under such circumstances, regardless of customer dependency, given the importance of the relationship, a focal supplier commits more resources to assure the success of international co-development activities, which then leads to more successful designs and improved supplier performance. Put differently, supplier dependency — created as a result of international customer involvement — compensates for the lack of customer commitment resulting from low levels of customer dependency. 


\subsection{Managerial Contributions}

Our research has a number of important managerial implications. In order to gain a better understanding of their international customers' needs and preferences, suppliers should have such customers involved in development of new designs. This would help them to assess whether a specific new product design feature/idea will be effective internationally, leading to better product-market fit and so enhanced supplier performance. However, managers should be aware of the impact of cultural differences. Our research highlights that a greater cultural distance means international customer involvement becomes less successful due to possible communication problems leading to misunderstanding and eventually to tension in interfirm relationships. Consequently, when the cultural distance is high, managers should disengage and consider terminating new design co-creation as a strategic move to enhance NPD project success. Such terminations release the sub-optimally invested resources that can be reinvested in other developments or relationships that potentially have a better business outcome (Zaefarian et al., 2017). In addition, our findings suggest that to increase the extent of international customer involvement in developing new designs, managers should invest in developing and maintaining interfirm relationship learning capabilities, which involve knowledge exchange and joint problem solving. This can be an effective way for suppliers to understand and respond to changes in foreign markets demands. Engaging international customers in co-creation activities is difficult due to geographical distances. Managers can overcome these challenges using relationship learning, leading to more successful crosscountry collaborations.

The findings indicate that when capitalizing on relationship learning, managers should pay attention to the extent to which their international customers depend on them. Relationship learning is a mutual and long-term activity; thus, to be effective, both firms should be committed to such activity. When customer dependency is high, the relationship with the 
supplier becomes more important, which in turn increases customer commitment and hence willingness to allocate important resources to the relationship. On the other hand, low level customer dependency decreases customer commitment and orientation towards cooperation. Hence, managers should be careful about how much time and resource they invest in relationship learning when customer dependency is low. Finally, our study finds that when the cultural distance is significant, relationship learning does not improve international customer involvement. Through increasing frictions and misunderstandings between suppliers and the international customer, cultural distance heightens the risk perceived by the supplier in engaging in international co-creation activities, which then dampens the effectiveness of relationship learning. Consequently, managers may benefit from evaluating cultural differences and their associated risks before investing in such relational capabilities.

\subsection{Limitations and Suggestions for Future Research}

While our study adds to the business literature in several important ways, it has a number of limitations that provide an avenue for the future research. Current literature recognizes different roles played by customers in terms of involvement in NPD namely, information providers, codevelopers, and innovators (e.g., Cui \& Wu, 2016). These roles vary based on the level of involvement the international customer has in NPD. Our study does not differentiate between these roles. Therefore, future research can explore the impact of relationship learning on each of these roles separately.

In addition, we have considered only the design stage, as it is one of the key stages of NPD (Menguc et al., 2014). We accept that the importance of international customer involvement on other stages of NPD may differ (Hoyer et al., 2010). Thus, a further development would be to study how relationship learning affects supplier performance through international customer involvement at other stages of the NPD process. Furthermore, we 
collected data from suppliers and not from customers. As a result, customer dependency measures are perceptual. While including customer dependency enabled us to investigate how it strengthens the relationship, there are some uncertainties related to the accuracy of managers' evaluation of customer dependency. Hence, it might be worthwhile to re-examine the moderating effects of customer dependency using both supplier and customer data.

Indeed, geographical distance have cost implications in terms of both complexity of knowledge search and the effectiveness of knowledge transfer (Ambos \& Ambos, 2009; Hansen \& Løvås, 2004). It could potentially jeopardize the efficiency of communication (Daft \& Lengel, 1986; Katz \& Allen, 1982), and as such create some obstacles to innovation generation in customer-supplier relationships (Jean et al., 2014). Hence future studies ought to control for this as well as other country level factors in their research. 


\section{References}

Abdi, M., \& Aulakh, P. S. (2012). Do country-level institutional frameworks and interfirm governance arrangements substitute or complement in international business relationships? Journal of International Business Studies, 43(5), 477-497.

Aiken, L. S., West, S., G. , \& Reno, R., R. . (1991). Multiple Regression: Testing and Interpreting Interactions: Sage Publication.

Al-Zu'bi, Z. b. M. F., \& Tsinopoulos, C. (2012). Suppliers versus Lead Users: Examining Their Relative Impact on Product Variety. Journal of Product Innovation Management, 29(4), 667-680.

Albort-Morant, G., Leal-Millán, A., \& Cepeda-Carrión, G. (2016). The antecedents of green innovation performance: A model of learning and capabilities. Journal of Business Research, 69(11), 4912-4917.

Ambos, T. C., \& Ambos, B. (2009). The impact of distance on knowledge transfer effectiveness in multinational corporations. Journal of International Management, $15(1), 1-14$.

Anning-Dorson, T. (2018). Customer involvement capability and service firm performance: The mediating role of innovation. Journal of Business Research, 86, 269-280.

Atuahene-Gima, K. (2005). Resolving the Capability-Rigidity Paradox in New Product Innovation. Journal of Marketing, 69(4), 61-83.

Bao, Y., Chen, X., \& Zhou, K. Z. (2012). External learning, market dynamics, and radical innovation: Evidence from China's high-tech firms. Journal of Business Research, 65(8), 1226-1233.

Barnes, B. R., Leonidou, L. C., Siu, N. Y. M., \& Leonidou, C. N. (2010). Opportunism as the Inhibiting Trigger for Developing Long-Term-Oriented Western Exporter-Hong Kong Importer Relationships. Journal of International Marketing, 18(2), 35-63.

Bendig, D., Enke, S., Thieme, N., \& Brettel, M. (2018). Performance implications of crossfunctional coopetition in new product development: the mediating role of organizational learning. Industrial Marketing Management, 73, 137-153.

Brouthers, L. E., O'Donnell, E., \& Hadjimarcou, J. (2005). Generic Product Strategies for Emerging Market Exports into Triad Nation Markets: A Mimetic Isomorphism Approach. Journal of Management Studies, 42(1), 225-245.

Carbonell, P., Rodríguez-Escudero, A. I., \& Pujari, D. (2009). Customer Involvement in New Service Development: An Examination of Antecedents and Outcomes*. Journal of Product Innovation Management, 26(5), 536-550.

Chang, W., \& Taylor, S. A. (2016). The Effectiveness of Customer Participation in New Product Development: A Meta-Analysis. Journal of Marketing, 80(1), 47-64.

Chatterji, A. K., \& Fabrizio, K. R. (2014). Using users: When does external knowledge enhance corporate product innovation? Strategic Management Journal, 35(10), 14271445.

Chen, Y.-S., Lin, M.-J. J., \& Chang, C.-H. (2009). The positive effects of relationship learning and absorptive capacity on innovation performance and competitive advantage in industrial markets. Industrial Marketing Management, 38(2), 152-158. 
Cheung, M.-S., Myers, M. B., \& Mentzer, J. T. (2010). Does relationship learning lead to relationship value? A cross-national supply chain investigation. Journal of Operations Management, 28(6), 472-487.

Cheung, M.-S., Myers, M. B., \& Mentzer, J. T. (2011). The value of relational learning in global buyer-supplier exchanges: a dyadic perspective and test of the pie-sharing premise. Strategic Management Journal, 32(10), 1061-1082.

Choi, J., \& Contractor, F. J. (2016). Choosing an appropriate alliance governance mode: The role of institutional, cultural and geographical distance in international research \& development (R\&D) collaborations. Journal of International Business Studies, 47(2), 210-232.

Cui, A. S., \& Wu, F. (2016). Utilizing customer knowledge in innovation: antecedents and impact of customer involvement on new product performance. Journal of the Academy of Marketing Science, 44(4), 516-538.

Cui, A. S., \& Wu, F. (2017). The Impact of Customer Involvement on New Product Development: Contingent and Substitutive Effects. Journal of Product Innovation Management, 34(1), 60-80. doi:10.1111/jpim.12326

Daft, R. L., \& Lengel, R. H. (1986). Organizational Information Requirements, Media Richness and Structural Design. Management Science, 32(5), 554-571.

Elia, S., Messeni Petruzzelli, A., \& Piscitello, L. (2019). The impact of cultural diversity on innovation performance of MNC subsidiaries in strategic alliances. Journal of Business Research, 98, 204-213.

Fang, E. (2008). Customer Participation and the Trade-Off between New Product Innovativeness and Speed to Market. Journal of Marketing, 72(4), 90-104.

Fang, E., Palmatier, R. W., \& Evans, K. R. (2008). Influence of customer participation on creating and sharing of new product value. Journal of the Academy of Marketing Science, 36(3), 322-336.

Fang, S.-R., Fang, S.-C., Chou, C.-H., Yang, S.-M., \& Tsai, F.-S. (2011). Relationship learning and innovation: The role of relationship-specific memory. Industrial Marketing Management, 40(5), 743-753.

Feng, T., Sun, L., \& Zhang, Y. (2010). The effects of customer and supplier involvement on competitive advantage: An empirical study in China. Industrial Marketing Management, 39(8), 1384-1394.

Gao, T., \& Shi, L. H. (2011). How Do Multinational Suppliers Formulate Mechanisms of Global Account Coordination? An Integrative Framework and Empirical Study. Journal of International Marketing, 19(4), 61-87.

Gençtürk, E. F., \& Aulakh, P. S. (2007). Norms- and Control-Based Governance of International Manufacturer-Distributor Relational Exchanges. Journal of International Marketing, 15(1), 92-126.

Griffith, D. A., \& Lee, H. S. (2016). Cross-National Collaboration of Marketing Personnel within a Multinational: Leveraging Customer Participation for New Product Advantage. Journal of International Marketing, 24(4), 1-19.

Gu, F. F., Wang, J. J., \& Wang, D. T. (2019). The role of sales representatives in crosscultural business-to-business relationships. Industrial Marketing Management, 78, 227-238. 
Hansen, M. T., \& Løvås, B. (2004). How do multinational companies leverage technological competencies? Moving from single to interdependent explanations. Strategic Management Journal, 25(8- 9), 801-822.

Heide, J. B., \& John, G. (1988). The Role of Dependence Balancing in Safeguarding Transaction-Specific Assets in Conventional Channels. Journal of Marketing, 52(1), 20-35.

Hewett, K., \& Krasnikov, A. V. (2016). Investing in Buyer-Seller Relationships in Transitional Markets: A Market-Based Assets Perspective. Journal of International Marketing, 24(1), 57-81.

Hofstede, G. H. (1980). Culture's Consequences: International Differences in Work-Related Values. Beverly Hill, CA: Sage Publication.

Hoyer, W. D., Chandy, R., Dorotic, M., Krafft, M., \& Singh, S. S. (2010). Consumer Cocreation in New Product Development. Journal of Service Research, 13(3), $283-$ 296.

Huikkola, T., Ylimäki, J., \& Kohtamäki, M. (2013). Joint learning in R\&D collaborations and the facilitating relational practices. Industrial Marketing Management, 42(7), 11671180.

Jap, S. D., \& Ganesan, S. (2000). Control Mechanisms and the Relationship Life Cycle: Implications for Safeguarding Specific Investments and Developing Commitment. Journal of Marketing Research, 37(2), 227-245.

Jean, R.-J. B., Kim, D., \& Sinkovics, R. R. (2012). Drivers and Performance Outcomes of Supplier Innovation Generation in Customer-Supplier Relationships: The Role of Power-Dependence. Decision Sciences, 43(6), 1003-1038.

Jean, R.-J. B., Sinkovics, R. R., \& Hiebaum, T. P. (2014). The Effects of Supplier Involvement and Knowledge Protection on Product Innovation in Customer-Supplier Relationships: A Study of Global Automotive Suppliers in China. Journal of Product Innovation Management, 31(1), 98-113.

Jean, R.-J. B., Sinkovics, R. R., \& Kim, D. (2010). Drivers and Performance Outcomes of Relationship Learning for Suppliers in Cross-Border Customer-Supplier Relationships: The Role of Communication Culture. Journal of International Marketing, 18(1), 63-85.

Jean, R. J. B., Kim, D., \& Bello, D. C. (2017). Relationship-based product innovations: Evidence from the global supply chain. Journal of Business Research, 80, 127-140.

Johnston, W. J., Khalil, S., Jain, M., \& Cheng, J. M.-S. (2012). Determinants of Joint Action in International Channels of Distribution: The Moderating Role of Psychic Distance. Journal of International Marketing, 20(3), 34-49.

Joshi, A. W., \& Sharma, S. (2004). Customer Knowledge Development: Antecedents and Impact on New Product Performance. Journal of Marketing, 68(4), 47-59.

Katsikeas, C. S., Samiee, S., \& Theodosiou, M. (2006). Strategy fit and performance consequences of international marketing standardization. Strategic Management Journal, 27(9), 867-890.

Katsikeas, C. S., Skarmeas, D., \& Bello, D. C. (2009). Developing successful trust-based international exchange relationships. Journal of International Business Studies, 40(1), 132-155. 
Katz, R., \& Allen, T. J. (1982). Investigating the Not Invented Here (NIH) syndrome: A look at the performance, tenure, and communication patterns of $50 \mathrm{R} \& \mathrm{D}$ Project Groups. $R \& D$ Management, $12(1), 7-20$.

Kim, Y. H., \& Henderson, D. (2015). Financial benefits and risks of dependency in triadic supply chain relationships. Journal of Operations Management, 36, 115-129.

Knudsen, M. P. (2007). The Relative Importance of Interfirm Relationships and Knowledge Transfer for New Product Development Success*. Journal of Product Innovation Management, 24(2), 117-138.

Kohtamäki, M., \& Partanen, J. (2016). Co-creating value from knowledge-intensive business services in manufacturing firms: The moderating role of relationship learning in supplier-customer interactions. Journal of Business Research, 69(7), 2498-2506.

Kogut, B., \& Singh, H. (1988). The Effect of National Culture on the Choice of Entry Mode. Journal of International Business Studies, 19(3), 411-432.

Kuester, S., Homburg, C., \& Hildesheim, A. (2017). The catbird seat of the sales force: How sales force integration leads to new product success. International Journal of Research in Marketing, 34(2), 462-479.

La Rocca, A., Moscatelli, P., Perna, A., \& Snehota, I. (2016). Customer involvement in new product development in B2B: The role of sales. Industrial Marketing Management, $58,45-57$.

Lai, C.-S., Pai, D.-C., Yang, C.-F., \& Lin, H.-J. (2009). The effects of market orientation on relationship learning and relationship performance in industrial marketing: The dyadic perspectives. Industrial Marketing Management, 38(2), 166-172.

Larwood, L., Falbe, C. M., Kriger, M. P., \& Miesing, P. (1995). Structure And Meaning Of Organizational Vision. Academy of Management Journal, 38(3), 740-769.

Lau, A. K. W., Tang, E., \& Yam, R. C. M. (2010). Effects of Supplier and Customer Integration on Product Innovation and Performance: Empirical Evidence in Hong Kong Manufacturers. Journal of Product Innovation Management, 27(5), 761-777.

Lavie, D., Haunschild, P. R., \& Khanna, P. (2012). Organizational differences, relational mechanisms, and alliance performance. Strategic Management Journal, 33(13), 14531479.

Lazzarini, S. G., Claro, D. P., \& Mesquita, L. F. (2008). Buyer-Supplier and SupplierSupplier Alliances: Do They Reinforce or Undermine One Another? Journal of Management Studies, 45(3), 561-584.

Leonidou, L. C., Katsikeas, C. S., \& Hadjimarcou, J. (2002). Executive Insights: Building Successful Export Business Relationships: A Behavioral Perspective. Journal of International Marketing, 10(3), 96-115.

Leonidou, L. C., Samiee, S., Aykol, B., \& Talias, M. A. (2014). Antecedents and Outcomes of Exporter-Importer Relationship Quality: Synthesis, Meta-Analysis, and Directions for Further Research. Journal of International Marketing, 22(2), 21-46.

Lew, Y. K., Sinkovics, R. R., Yamin, M., \& Khan, Z. (2016). Trans-specialization understanding in international technology alliances: The influence of cultural distance. Journal of International Business Studies, 47(5), 577-594.

Lindell, M. K., \& Whitney, D. J. (2001). Accounting for common method variance in crosssectional research designs. Journal of Applied Psychology, 86(1), 114-121. 
Ling-yee, L. (2006). Relationship learning at trade shows: Its antecedents and consequences. Industrial Marketing Management, 35(2), 166-177.

Liu, S. S., Luo, X., \& Shi, Y.-Z. (2003). Market-oriented organizations in an emerging economy: A study of missing links. Journal of Business Research, 56(6), 481-491.

Luchs, M. G., Swan, K. S., \& Creusen, M. E. H. (2016). Perspective: A Review of Marketing Research on Product Design with Directions for Future Research. Journal of Product Innovation Management, 33(3), 320-341.

Mahr, D., Lievens, A., \& Blazevic, V. (2014). The Value of Customer Cocreated Knowledge during the Innovation Process. Journal of Product Innovation Management, 31(3), 599-615.

McGrath, H., \& O'Toole, T. (2014). A cross-cultural comparison of the network capability development of entrepreneurial firms. Industrial Marketing Management, 43(6), 897910.

Melton, H. L., \& Hartline, M. D. (2010). Customer and Frontline Employee Influence on New Service Development Performance. Journal of Service Research, 13(4), 411425.

Menguc, B., Auh, S., \& Yannopoulos, P. (2014). Customer and Supplier Involvement in Design: The Moderating Role of Incremental and Radical Innovation Capability. Journal of Product Innovation Management, 31(2), 313-328.

Mitrega, M., Forkmann, S., Zaefarian, G. and Henneberg, S.C., (2017). Networking capability in supplier relationships and its impact on product innovation and firm performance. International Journal of Operations \& Production Management, 37(5), 577-606.

Morgan, T., Obal, M., \& Anokhin, S. (2018). Customer participation and new product performance: Towards the understanding of the mechanisms and key contingencies. Research Policy, 47(2), 498-510.

Moultrie, J., Clarkson, P. J., \& Probert, D. (2007). Development of a Design Audit Tool for SMEs. Journal of Product Innovation Management, 24(4), 335-368.

Najafi-Tavani, Z., Robson, M.J., Zaefarian, G., Andersson, U. and Yu, C., (2018). Building subsidiary local responsiveness:(When) does the directionality of intrafirm knowledge transfers matter?. Journal of World Business, 53(4), 475-492.

Narver, J. C., Slater, S. F., \& MacLachlan, D. L. (2004). Responsive and Proactive Market Orientation and New-Product Success. Journal of Product Innovation Management, 21(5), 334-347.

Newbert, S. L. (2007). Empirical research on the resource-based view of the firm: an assessment and suggestions for future research. Strategic Management Journal, 28(2), 121-146.

Ngo, L. V., \& O'Cass, A. (2013). Innovation and business success: The mediating role of customer participation. Journal of Business Research, 66(8), 1134-1142.

Palmatier, R. W., Dant, R. P., \& Grewal, D. (2007). A Comparative Longitudinal Analysis of Theoretical Perspectives of Interorganizational Relationship Performance. Journal of Marketing, 71(4), 172-194.

Petrin, A., \& Train, K. (2010). A Control Function Approach to Endogeneity in Consumer Choice Models. Journal of Marketing Research, 47(1), 3-13. 
Phelps, C. C. (2010). A Longitudinal Study of the Influence of Alliance Network Structure and Composition on Firm Exploratory Innovation. Academy of Management Journal, 53(4), 890-913.

Podsakoff, P. M., MacKenzie, S. B., Lee, J. Y., \& Podsakoff, N. P. (2003). Common Method Biases in Behavioral Research: A Critical Review of the Literature and Recommended Remedies. Journal of Applied Psychology, 885(879), 10-37.

Poppo, L., \& Zhou, K. Z. (2014). Managing contracts for fairness in buyer-supplier exchanges. Strategic Management Journal, 35(10), 1508-1527.

Poppo, L., Zhou, K. Z., \& Li, J. J. (2016). When can you trust "trust"? Calculative trust, relational trust, and supplier performance. Strategic Management Journal, 37(4), 724741.

Rosenbloom, B., \& Larsen, T. (2003). Communication in international business-to-business marketing channels: Does culture matter? Industrial Marketing Management, 32(4), 309-315.

Ryu, S., Park, J. E., \& Min, S. (2007). Factors of determining long-term orientation in interfirm relationships. Journal of Business Research, 60(12), 1225-1233.

Saldanha, T. J. V., Mithas, S., \& Krishnan, M. S. (2017). Leveraging Customer Involvement for Fueling Innovation: The Role of Relational and Analytical Information Processing Capabilities. MIS Quarterly, 41(1), 267-A211.

Scheer, L. K., Miao, C. F., \& Garrett, J. (2010). The effects of supplier capabilities on industrial customers' loyalty: the role of dependence. Journal of the Academy of Marketing Science, 38(1), 90-104.

Schmitt, A., \& Van Biesebroeck, J. (2013). Proximity strategies in outsourcing relations: The role of geographical, cultural and relational proximity in the European automotive industry. Journal of International Business Studies, 44(5), 475-503.

Selnes, F., \& Sallis, J. (2003). Promoting Relationship Learning. Journal of Marketing, 67(3), 80-95.

Shiu, E., Jiang, Z. and Zaefarian, G., (2014). Antecedents of behavioural commitment in inter-organizational relationships: a field study of the UK construction industry.Construction Management and Economics 32(9), 888-903.

Skaggs, B. C., \& Youndt, M. (2004). Strategic positioning, human capital, and performance in service organizations: a customer interaction approach. Strategic Management Journal, 25(1), 85-99.

Skarmeas, D., Katsikeas, C. S., \& Schlegelmilch, B. B. (2002). Drivers of Commitment and its Impact on Performance in Cross-Cultural Buyer-Seller Relationships: The Importer's Perspective. Journal of International Business Studies, 33(4), 757-783.

Smets, L. P. M., Langerak, F., \& Rijsdijk, S. A. (2013). Shouldn't Customers Control Customized Product Development? Journal of Product Innovation Management, 30(6), 1242-1253.

Sousa, C. M. P., \& Bradley, F. (2006). Cultural Distance and Psychic Distance: Two Peas in a Pod? Journal of International Marketing, 14(1), 49-70.

Statista. (2020). Top 20 export countries worldwide in 2018. Retrieved from https://www.statista.com/statistics/264623/leading-export-countries-worldwide/ 
Storey, C., \& Larbig, C. (2018). Absorbing Customer Knowledge:How Customer Involvement Enables Service Design Success. Journal of Service Research, 21(1), 101-118.

Svendsen, F. M., Haugland, S., A., Grønhaug, K., \& Hammervoll, T. (2011). Marketing strategy and customer involvement in product development. European Journal of Marketing, 45(4), 513-530.

Ullah, S., Zaefarian, G., \& Ullah, F. (2020). How to use instrumental variables in addressing endogeneity? A step-by-step procedure for non-specialists. Industrial Marketing Management. In Press

Ulrich, K. T. (2011). Design Is Everything? Journal of Product Innovation Management, 28(3), 394-398.

Veryzer, R. W., \& Borja de Mozota, B. (2005). The Impact of User-Oriented Design on New Product Development: An Examination of Fundamental Relationships*. Journal of Product Innovation Management, 22(2), 128-143.

Wang, Q., Bradford, K., Xu, J., \& Weitz, B. (2008). Creativity in buyer-seller relationships: The role of governance. International Journal of Research in Marketing, 25(2), 109118.

Wang, Y., Lee, J., Fang, E., \& Ma, S. (2017). Project Customization and the Supplier Revenue-Cost Dilemmas: The Critical Roles of Supplier-Customer Coordination. Journal of Marketing, 81(1), 136-154.

West, J., Salter, A., Vanhaverbeke, W., \& Chesbrough, H. (2014). Open innovation: The next decade. Research Policy, 43(5), 805-811.

Yan, T., \& Dooley, K. (2014). Buyer-Supplier Collaboration Quality in New Product Development Projects. Journal of Supply Chain Management, 50(2), 59-83.

Yeniyurt, S., Henke, J. W., \& Yalcinkaya, G. (2014). A longitudinal analysis of supplier involvement in buyers' new product development: working relations, interdependence, co-innovation, and performance outcomes. Journal of the Academy of Marketing Science, 42(3), 291-308.

Zaefarian, G., Forkmann, S., Mitręga, M., \& Henneberg, S. C. (2017). A Capability Perspective on Relationship Ending and Its Impact on Product Innovation Success and Firm Performance. Long Range Planning, 50(2), 184-199.

Zaefarian, G., Kadile, V., Henneberg, S. C., \& Leischnig, A. (2017). Endogeneity bias in marketing research: Problem, causes and remedies. Industrial Marketing Management, 65, 39-46.

Zhang, X., Zhong, W., \& Makino, S. (2015). Customer involvement and service firm internationalization performance: An integrative framework. Journal of International Business Studies, 46(3), 355-380.

Zhou, K. Z., \& Li, C. B. (2012). How knowledge affects radical innovation: Knowledge base, market knowledge acquisition, and internal knowledge sharing. Strategic Management Journal, 33(9), 1090-1102.

Zhou, K. Z., Tse, D. K., \& Li, J. J. (2006). Organizational changes in emerging economies: drivers and consequences. Journal of International Business Studies, 37(2), 248-263. 
Zhou, K. Z., Zhang, Q., Sheng, S., Xie, E., \& Bao, Y. (2014). Are relational ties always good for knowledge acquisition? Buyer-supplier exchanges in China. Journal of Operations Management, 32(3), 88-98. 
Table 1: Selected Empirical studies on antecedences and consequences of business customer involvement

\begin{tabular}{|c|c|c|c|c|c|}
\hline Source & $\begin{array}{l}\text { Conceptualization / context } \\
\text { and sample }\end{array}$ & Antecedences & Consequences & Moderators & Summary of Key Findings \\
\hline Joshi \& Sharma (2004) & $\begin{array}{l}\text { Customer involvement } \\
\text { (customer knowledge } \\
\text { development) of group of } \\
\text { customers/Survey of } 169 \\
\text { manufacturing firms in } \\
\text { Canada }\end{array}$ & $\begin{array}{l}\text { - Provision of resource slack } \\
\text { - Intelligent-failure reward } \\
\text { system } \\
\text { - Creation of cross- } \\
\text { functional new product } \\
\text { development teams } \\
\text { - Integration mode of } \\
\text { conflict resolution } \\
\text { - Championing the } \\
\text { organizational goal of } \\
\text { product leadership } \\
\text { - Projects members' goal of } \\
\text { product leadership }\end{array}$ & New product performance & -- & $\begin{array}{l}\text { Provision of resource slack positively related to customer knowledge } \\
\text { development only under high level of intelligent-failure reward system. } \\
\text { Creation of cross-functional new product development teams positively } \\
\text { affects new product performance and this association is stronger under high } \\
\text { level of integration mode of conflict resolution. Championing the } \\
\text { organizational goal of product leadership positively affects new product } \\
\text { performance. }\end{array}$ \\
\hline $\begin{array}{l}\text { Skaggs \& Youndt } \\
\text { (2004) }\end{array}$ & $\begin{array}{l}\text { Customer involvement } \\
\text { (customer co-production) of } \\
\text { groups of customers/ Survey } \\
\text { of } 234 \text { service firms in the } \\
\text { US }\end{array}$ & -- & $\begin{array}{l}\text {-Human capital } \\
\text { - Firm performance }\end{array}$ & Human capital & $\begin{array}{l}\text { Customer co-production negatively affects human capital. Human capital } \\
\text { negatively moderates the relationship between customer co-production and } \\
\text { firm performance }\end{array}$ \\
\hline Knudsen (2007) & $\begin{array}{l}\text { Customer involvement of } \\
\text { groups of customers/ Survey } \\
\text { of } 557 \text { manufacturing and } \\
\text { service firms across Europe }\end{array}$ & -- & - Innovative performance & -- & Customer involvement negatively affects innovative performance \\
\hline $\begin{array}{l}\text { Fang, Palmatier, \& } \\
\text { Evans (2008) }\end{array}$ & $\begin{array}{l}\text { Customer involvement } \\
\text { (customer participation) of a } \\
\text { single customer/ Survey of } \\
188 \text { manufacturing firms } \\
\text { (country was not specified) }\end{array}$ & -- & $\begin{array}{l}\text { - Supplier relationship- } \\
\text { specific investment } \\
\text { - Customer relationship- } \\
\text { specific investment } \\
\text { - Information sharing } \\
\text { - Coordination } \\
\text { effectiveness } \\
\text { - New product value } \\
\text { - Customer perception of } \\
\text { "fair share" } \\
\text { - New product value } \\
\text { obtained by customer } \\
\text { - Customer dependence } \\
\text { - Supplier dependence } \\
\end{array}$ & $\begin{array}{l}\text { Customer participation } \\
\text { formality }\end{array}$ & $\begin{array}{l}\text { Customer participation positively affects information sharing, coordination } \\
\text { effectiveness, customer and supplier relationship-specific investment. The } \\
\text { association between customer participation and customer and supplier } \\
\text { relationship-specific investment is positively moderated by customer } \\
\text { participation formality. }\end{array}$ \\
\hline Fang (2008) & $\begin{array}{l}\text { Customer involvement } \\
\text { (customer participation) of a } \\
\text { single customer/ Survey of } \\
143 \text { manufacturing firms } \\
\text { (country was not specified) }\end{array}$ & -- & $\begin{array}{l}\text { - New product } \\
\text { innovativeness } \\
\text { - New product speed to } \\
\text { market }\end{array}$ & $\begin{array}{l}\text { - Customer network } \\
\text { connectivity } \\
\text { - Process interdependence } \\
\text { - Process complexity }\end{array}$ & $\begin{array}{l}\text { Customer participation as information provider positively affects new } \\
\text { product speed to market and this association is positively moderated by } \\
\text { downstream customer network connectivity. Downstream customer } \\
\text { network connectivity negatively moderates the association between } \\
\text { customer participation as information provider and new product } \\
\text { innovativeness. Process interdependence negatively moderates the } \\
\text { relationship between customer participation as co-creator and new product } \\
\text { speed to market. Process interdependence positively moderates the } \\
\text { relationship between customer participation as co-creator and new product } \\
\text { innovativeness. }\end{array}$ \\
\hline Carbonell et al. (2009) & $\begin{array}{l}\text { Customer involvement of } \\
\text { group of customers/ } 102 \\
\text { service firms in Spain }\end{array}$ & $\begin{array}{l}\text { - Technological novelty } \\
\text { - Technological turbulence }\end{array}$ & $\begin{array}{l}\text { - Innovation speed } \\
\text {-Technical quality } \\
\text { - Competitive superiority }\end{array}$ & $\begin{array}{l}\text { Stage of the process } \\
\text { development }\end{array}$ & $\begin{array}{l}\text { Customer involvement positively affects technical quality and innovation } \\
\text { speed, but does not directly affect competitive superiority and sale } \\
\text { performance. Technological turbulence positively affects customer }\end{array}$ \\
\hline
\end{tabular}




\begin{tabular}{|c|c|c|c|c|c|}
\hline & & & - Sale performance & & $\begin{array}{l}\text { involvement. Stage of the process development does not moderate the } \\
\text { consequences of customer involvement. }\end{array}$ \\
\hline Feng et al. (2010) & $\begin{array}{l}\text { Customer involvement of } \\
\text { group of customers/Survey } \\
\text { of } 139 \text { firms operating in } \\
\text { various industries in China }\end{array}$ & -- & $\begin{array}{l}\text { - Cost leadership } \\
\text {-Product quality } \\
\text { - Delivery reliability } \\
\text { - Process flexibility } \\
\text { - Customer service } \\
\end{array}$ & -- & $\begin{array}{l}\text { Customer involvement positively affect product quality, delivery reliability, } \\
\text { process flexibility, and customer service. }\end{array}$ \\
\hline $\begin{array}{l}\text { Lau, Tang, \& Yam } \\
\text { (2010) }\end{array}$ & $\begin{array}{l}\text { Customer involvement } \\
\text { (product co-development) of } \\
\text { groups of customers/ Survey } \\
\text { of } 251 \text { manufacturing firms } \\
\text { in China }\end{array}$ & -- & $\begin{array}{l}\text { - Product performance } \\
\text { - Product innovation }\end{array}$ & -- & $\begin{array}{l}\text { Product co-development with customer positively affects product } \\
\text { performance. }\end{array}$ \\
\hline $\begin{array}{l}\text { Melton \& Hartline } \\
\text { (2010) }\end{array}$ & $\begin{array}{l}\text { Customer involvement of } \\
\text { group of customers/ Survey } \\
\text { of } 160 \text { service firm in the US }\end{array}$ & -- & $\begin{array}{l}\text { - Service marketability } \\
\text { - Launch preparation }\end{array}$ & -- & $\begin{array}{l}\text { Customer involvement in design positively affects launch preparation and } \\
\text { service marketability. Customer involvement in development positively } \\
\text { affects launch preparation. However, Customer involvement in full launch } \\
\text { does not have any significant effect on service marketability. }\end{array}$ \\
\hline Svendsen et al. (2011) & $\begin{array}{l}\text { Customer involvement of a } \\
\text { single customer/ Survey of } \\
324 \text { manufacturers in } \\
\text { Norway }\end{array}$ & $\begin{array}{l}\text { - Product differentiation } \\
\text { - Competitor orientation } \\
\text { - Brand profiling emphasize } \\
\text { - Supplier specific } \\
\text { investment }\end{array}$ & Relationship profitability & -- & $\begin{array}{l}\text { - Competitor orientation and supplier-spec investments positively affect } \\
\text { customer involvement. Customer involvement positively affects } \\
\text { relationship profitability. }\end{array}$ \\
\hline $\begin{array}{l}\text { Al-Zu'bi \& } \\
\text { Tsinopoulos (2012) }\end{array}$ & $\begin{array}{l}\text { Customer involvement } \\
\text { (collaboration with lead } \\
\text { users) of group of customers/ } \\
\text { Survey of } 313 \text { manufacturing } \\
\text { firms in the UK }\end{array}$ & -- & Product variety & -- & Collaboration with lead users positively affects product variety. \\
\hline Ngo \& O'Cass (2013) & $\begin{array}{l}\text { Customer involvement } \\
\text { (customer participation) of } \\
\text { group of customers/Survey } \\
\text { of } 155 \text { Australian service } \\
\text { firms }\end{array}$ & $\begin{array}{l}\text { - Technical innovation } \\
\text { capability } \\
\text { - Non technical innovation } \\
\text { capability }\end{array}$ & $\begin{array}{l}\text { - Firm performance } \\
\text { - Service quality }\end{array}$ & -- & $\begin{array}{l}\text { Customer participation fully mediates the relationship between technical } \\
\text { innovation capability and service quality. It, however, partially mediates } \\
\text { the relationship between non-technical innovation capability and service } \\
\text { quality. Service quality positively affects firm performance. }\end{array}$ \\
\hline $\begin{array}{l}\text { Smets, Langerak, \& } \\
\text { Rijsdijk (2013) }\end{array}$ & $\begin{array}{l}\text { Customer involvement } \\
\text { (customer participation) of a } \\
\text { single customer/ Survey of } \\
63 \text { collaborative projects } \\
\text { between a focal } \\
\text { manufacturer and its } \\
\text { customers }\end{array}$ & $\begin{array}{l}\text { - Process control } \\
\text { - Output control }\end{array}$ & $\begin{array}{l}\text { - New product } \\
\text { performance }\end{array}$ & -- & $\begin{array}{l}\text { Process and output control positively affect customer participation. } \\
\text { Customer participation positively affects new product performance. }\end{array}$ \\
\hline $\begin{array}{l}\text { Chatterji \& Fabrizio } \\
\text { (2014) }\end{array}$ & $\begin{array}{l}\text { Customer involvement } \\
\text { (inventive collaborations } \\
\text { with product users) of groups } \\
\text { of customers/ Panel dataset } \\
\text { of medical firms in the US }\end{array}$ & -- & $\begin{array}{l}\text { - Corporate innovative } \\
\text { performance }\end{array}$ & $\begin{array}{l}\text { - New/old technology area } \\
\text { - Radical/incremental } \\
\text { innovations }\end{array}$ & $\begin{array}{l}\text { Inventive collaborations with product users positively affects corporate } \\
\text { innovative performance and this association positively moderated by new } \\
\text { technology and radical innovation. }\end{array}$ \\
\hline $\begin{array}{l}\text { Mahr, Lievens, \& } \\
\text { Blazevic (2014) }\end{array}$ & $\begin{array}{l}\text { Customer involvement } \\
\text { (value of customer co- } \\
\text { created knowledge) of a } \\
\text { single customer/ Survey of } \\
126 \text { service firms across } \\
\text { Europe }\end{array}$ & $\begin{array}{l}\text { - Closeness in customer-firm } \\
\text { relationship } \\
\text { - Lead user status }\end{array}$ & $\begin{array}{l}\text { - Market/ financial success } \\
\text { - Customer acceptance } \\
\text { - Learning success }\end{array}$ & Communication channels & $\begin{array}{l}\text { Customer acceptance and learning success positively affect market/ } \\
\text { financial success. Knowledge relevance positively affects customer } \\
\text { acceptance and learning success. Knowledge novelty has an inverted U } \\
\text { shape relationship with customer acceptance and it positively affects } \\
\text { learning success. Knowledge costs negatively affects customer acceptance. } \\
\text { Lead user status positively affects knowledge relevance and novelty. } \\
\text { Closeness in customer-firm relationship positively affects knowledge } \\
\text { relevannece but negatively affects knowledge costs. Face to face } \\
\text { communication negatively moderated the association between closeness in } \\
\text { customer--firm relationship and knowledge novelty. Bit to bit } \\
\text { communication negatively moderated the association between closeness in } \\
\text { customer--ifrm relationship and knowledge costs. Voice to voice } \\
\text { communication positively moderated the association between lead user } \\
\text { status and relevance. }\end{array}$ \\
\hline
\end{tabular}




\begin{tabular}{|c|c|c|c|c|c|}
\hline Menguc et al. (2014) & $\begin{array}{l}\text { Customer involvement of } \\
\text { group of customers/ Survey } \\
\text { of } 216 \text { high-tech industries in } \\
\text { Canada }\end{array}$ & -- & - Product performance & $\begin{array}{l}\text { - Incremental product } \\
\text { innovation capability } \\
\text { - Radical product } \\
\text { innovation capability }\end{array}$ & $\begin{array}{l}\text { Customer involvement positively affects new product performance. Radical } \\
\text { innovation capability negatively and incremental innovation capability } \\
\text { positively moderate this association. }\end{array}$ \\
\hline Zhang et al. (2015) & $\begin{array}{l}\text { Customer involvement of } \\
\text { group of customers/ survey } \\
\text { of } 208 \text { service firms in China }\end{array}$ & $\begin{array}{l}\text { - Legitimacy pressure } \\
\text { - Market ambiguity }\end{array}$ & $\begin{array}{l}\text { Internationalization } \\
\text { performance }\end{array}$ & $\begin{array}{l}\text { - Relational capability } \\
\text { - Absorptive capacity }\end{array}$ & $\begin{array}{l}\text { Customer involvement positively affects internationalization performance. } \\
\text { Legitimacy pressure positively affects customer involvement. Relational } \\
\text { capability positively moderates the relationship between legitimacy } \\
\text { pressure and customer involvement. }\end{array}$ \\
\hline Griffith \& Lee (2016) & $\begin{array}{l}\text { Customer involvement } \\
\text { (customer participation) of } \\
\text { groups of customers/ Survey } \\
\text { of } 201 \text { firms in the US }\end{array}$ & -- & New product advantage & $\begin{array}{l}\text { Cross-national } \\
\text { collaboration }\end{array}$ & $\begin{array}{l}\text { Customer participation as co-developer and information provider have no } \\
\text { significant effects on new product advantage. Cross-national collaboration } \\
\text { positively moderates the association between customer participation as } \\
\text { information provider and new product advantages. Cross-national } \\
\text { collaboration negatively moderates the association between customer } \\
\text { participation as co-developer and new product advantages. }\end{array}$ \\
\hline Cui \& Wu (2016) & $\begin{array}{l}\text { Customer involvement of } \\
\text { group of customers/ Survey } \\
\text { of } 245 \text { firms operating in } \\
\text { various industries in the US }\end{array}$ & $\begin{array}{l}\text { - Customer need } \\
\text { heterogeneity } \\
\text { - Customer need tacitness } \\
\text { - Market exploitation } \\
\text { - Market exploration } \\
\text { - Inter-functional } \\
\text { coordination } \\
\text { - Strategic flexibility }\end{array}$ & $\begin{array}{l}\text { - New product } \\
\text { performance }\end{array}$ & - Technological capability & $\begin{array}{l}\text { Customer involvement as co-creator positively influence new product } \\
\text { performance and that this relationship is negatively moderated by } \\
\text { technological capabilitity. Customere need heterogeneity, market exploitation, } \\
\text { and inter-functional coordination positively and market exploration } \\
\text { negatively affects customer involvement as co-creator. Customer need } \\
\text { tacitness negatively and market exploitation and inter-functional } \\
\text { coordination positively affect customer involvement as information } \\
\text { provider. }\end{array}$ \\
\hline Cui \& Wu (2017) & $\begin{array}{l}\text { Customer involvement of } \\
\text { group of customers/ Survey } \\
\text { of } 245 \text { firms operating in } \\
\text { various industries in the US }\end{array}$ & -- & $\begin{array}{l}\text { - New product } \\
\text { innovativeness } \\
\text { - New product advantage } \\
\text { - New product financial } \\
\text { performance }\end{array}$ & $\begin{array}{l}\text { Experimental NPD } \\
\text { approach }\end{array}$ & $\begin{array}{l}\text { Customer involvement as information source positively affects new product } \\
\text { innovativeness and that this relationshipi is positively moderated by } \\
\text { experimental NPD approach. Customer involvement as a co-creator } \\
\text { positively affects new product innovativeness only under high level of } \\
\text { experimental NPD approach. New product innovativeness positively affects } \\
\text { new product financial performance only through new product advantage. }\end{array}$ \\
\hline Saldanha et al. (2017) & $\begin{array}{l}\text { Customer involvement of } \\
\text { group of } \\
\text { customers/Secondary data of } \\
310 \text { manufacturing firms in } \\
\text { the US }\end{array}$ & -- & Amount of innovation & $\begin{array}{l}\text { Analytical and relational } \\
\text { information processing } \\
\text { capability }\end{array}$ & $\begin{array}{l}\text { Both product and information based customer involvement positively affect } \\
\text { amount of innovation and these relationships are positively moderated by } \\
\text { analytical and relational information processing capabilities. }\end{array}$ \\
\hline Anning-Dorson (2018) & $\begin{array}{l}\text { Customer involvement } \\
\text { capability of group of } \\
\text { customers/ Survey of } 201 \\
\text { service firms located in } \\
\text { Ghana and } 171 \text { service firms } \\
\text { located in the UK }\end{array}$ & -- & $\begin{array}{l}\text { - Service firm } \\
\text { performance } \\
\text { - Product innovation } \\
\text { - Process Innovation }\end{array}$ & $\begin{array}{l}\text { - Country (i.e. Ghana and } \\
\text { UK) }\end{array}$ & $\begin{array}{l}\text { Customer involvement affects firm performance positively in Ghana and } \\
\text { negatively in the UK. The link between customer involvement and product } \\
\text { innovation is mediated by product and process innovation within both } \\
\text { contexts. }\end{array}$ \\
\hline $\begin{array}{l}\text { Morgan, Obal, \& } \\
\text { Anokhin (2018) }\end{array}$ & $\begin{array}{l}\text { Customer involvement } \\
\text { (customer participation) of } \\
\text { groups of customers/ Survey } \\
\text { of } 243 \text { manufacturing firms } \\
\text { in the US }\end{array}$ & -- & $\begin{array}{l}\text { - New product } \\
\text { performance } \\
\text { - New product } \\
\text { innovativeness }\end{array}$ & Absorptive capacity & $\begin{array}{l}\text { Customer participation positively affects new product performance and } \\
\text { innovativeness. Absorptive capacity positively moderates these } \\
\text { associations. }\end{array}$ \\
\hline Storey \& Larbig (2018) & $\begin{array}{l}\text { Customer involvement of } \\
\text { group of customers/ Survey } \\
\text { of } 126 \text { leading international } \\
\text { service firms operation in } \\
\text { various countries. }\end{array}$ & -- & $\begin{array}{l}\text { - Customer knowledge } \\
\text { assimilation } \\
\text { - Concept transformation } \\
\text { - New service success }\end{array}$ & Resource slack & $\begin{array}{l}\text { Customer involvement positively affects customer knowledge assimilation } \\
\text { and concept transformation. } \\
\text { Customer knowledge assimilation positively affects concept transformation } \\
\text { and new product success. Concept transformation positively affects new } \\
\text { service success only under high level of resource slack. }\end{array}$ \\
\hline This Study & $\begin{array}{l}\text { Customer involvement// } \\
\text { Survey of } 264 \text { manufacturing } \\
\text { firms in China }\end{array}$ & Relationship Learning & Supplier Performance & $\begin{array}{l}\text { - Buyer Dependence on } \\
\text { Supplier } \\
\text { - Cultural Distance }\end{array}$ & $\begin{array}{l}\text { Customer involvement positively affects supplier performance. } \\
\text { Relationship learning positively affects customer involvement and supplier } \\
\text { performance. Cultural distance and customer dependence positively } \\
\text { moderate the association between relationship learning and customer } \\
\text { involvement. Cultural distance and customer dependence positively } \\
\text { moderate the association between customer involvement and supplier } \\
\text { performance. }\end{array}$ \\
\hline
\end{tabular}


Table 2: Descriptive Profile of Respondents

\begin{tabular}{lc} 
Respondents' Profile & Percent \\
\hline Industry & \\
Information technology & $26 \%$ \\
Electronic & $22.5 \%$ \\
Mechanical and electric equipment & $14.7 \%$ \\
Pharmaceuticals & $12.9 \%$ \\
Chemicals and allied & $12.5 \%$ \\
Apparel & $11.4 \%$ \\
\hline Managerial grade & \\
Top executives & \\
(presidents, CEOs, and vice presidents) & $65.5 \%$ \\
Sales managers & $20.8 \%$ \\
R\&D managers & $12.2 \%$ \\
Production managers & $1.5 \%$
\end{tabular}


Table 3: Descriptive Statistics

\begin{tabular}{|c|c|c|c|c|c|c|c|c|c|c|c|c|c|c|c|c|c|c|c|c|c|}
\hline Construct & 1 & 2 & 3 & 4 & 5 & 6 & 7 & 8 & 9 & 10 & 11 & 12 & 13 & 14 & 15 & 16 & 17 & 18 & 19 & 20 & 21 \\
\hline 1. Information Sharing & $\underline{0.72}$ & 0.60 & 0.64 & 0.25 & 0.01 & 0.36 & 0.32 & 0.35 & 0.34 & 0.28 & 0.17 & 0.26 & 0.14 & 0.34 & 0.05 & -0.02 & 0.11 & 0.37 & 0.25 & 0.18 & 0.05 \\
\hline 2. Joint Sensemaking & $\overline{0.61} * *$ & $\underline{0.73}$ & 0.70 & 0.30 & 0.01 & 0.36 & 0.37 & 0.45 & 0.46 & 0.21 & 0.22 & 0.18 & 0.19 & 0.33 & 0.08 & 0.02 & 0.15 & 0.34 & 0.20 & 0.22 & 0.05 \\
\hline 3. Knowledge Integration & $0.65^{* *}$ & $\overline{0.71} * *$ & $\underline{0.72}$ & 0.28 & 0.02 & 0.38 & 0.39 & 0.44 & 0.41 & 0.14 & 0.22 & 0.18 & 0.21 & 0.38 & 0.07 & 0.02 & 0.13 & 0.41 & 0.26 & 0.19 & 0.09 \\
\hline $\begin{array}{l}\text { 4. International Customer } \\
\text { Involvement in the design stage }\end{array}$ & $0.26 * *$ & $0.31 * *$ & $\overline{0.29} * *$ & $\underline{0.79}$ & -0.11 & 0.10 & 0.22 & 0.25 & 0.32 & 0.16 & 0.13 & 0.00 & 0.10 & 0.10 & 0.02 & 0.07 & 0.08 & 0.30 & 0.08 & 0.00 & 0.04 \\
\hline 5. Cultural Distance & 0.02 & 0.02 & 0.03 & -0.10 & $\underline{\mathbf{N A}}$ & -0.17 & 0.11 & 0.12 & 0.09 & 0.07 & -0.02 & 0.09 & -0.02 & -0.10 & 0.03 & 0.02 & -0.02 & 0.02 & 0.01 & 0.29 & -0.03 \\
\hline 6. Customer Dependence & $0.37 * *$ & $0.37 * *$ & $0.39 * *$ & 0.11 & $\overline{-0.16 * *}$ & $\underline{0.78}$ & 0.24 & 0.21 & 0.22 & 0.03 & 0.16 & 0.24 & 0.11 & 0.42 & 0.00 & -0.04 & 0.13 & 0.29 & 0.21 & 0.15 & 0.09 \\
\hline 7. Sales Performance & $0.33 * *$ & $0.38 * *$ & $0.40 * *$ & $0.23 * *$ & $0.12 *$ & $\overline{0.25}$ ** & $\underline{0.75}$ & 0.76 & 0.75 & 0.09 & 0.07 & 0.18 & 0.09 & 0.23 & 0.10 & 0.09 & 0.21 & 0.28 & 0.18 & 0.18 & 0.06 \\
\hline 8. Financial Performance & $0.36 * *$ & $0.46 * *$ & $0.45^{* *}$ & $0.26 * *$ & $0.13 *$ & $0.22 * *$ & 0.77 ** & $\underline{0.80}$ & 0.70 & 0.14 & 0.11 & 0.12 & 0.10 & 0.18 & 0.07 & 0.03 & 0.13 & 0.28 & 0.15 & 0.17 & 0.04 \\
\hline 9. Customer Performance & $0.35^{* *}$ & $0.47 * *$ & $0.42 * *$ & $0.33 * *$ & 0.10 & $0.23^{* *}$ & $0.76^{\text {** }}$ & $\overline{0.71} * *$ & $\underline{0.77}$ & 0.07 & 0.03 & 0.12 & 0.06 & 0.20 & 0.10 & 0.02 & 0.17 & 0.28 & 0.22 & 0.19 & 0.03 \\
\hline 10. Supplier Size & $0.29 * *$ & $0.22 * *$ & $0.15^{*}$ & $0.17 * *$ & 0.08 & 0.04 & 0.10 & $0.15^{*}$ & $\overline{0.08}$ & NA & 0.29 & 0.29 & 0.29 & 0.07 & -0.02 & 0.12 & 0.11 & 0.11 & 0.05 & 0.22 & 0.00 \\
\hline 11. Supplier Age & $0.18^{* *}$ & $0.23 * *$ & $0.23 * *$ & $0.14 *$ & -0.01 & $0.17 * *$ & 0.08 & $0.12 *$ & 0.04 & $\overline{0.30} * *$ & NA & 0.39 & 0.66 & 0.17 & -0.06 & 0.09 & 0.15 & 0.08 & -0.09 & 0.00 & 0.57 \\
\hline 12. Relationship Age & $0.27 * *$ & $0.19 * *$ & $0.19 * *$ & 0.01 & 0.10 & $0.25 * *$ & $0.19 * *$ & $0.13 *$ & $0.13 *$ & $0.30 * *$ & $0.40 * *$ & NA & 0.44 & 0.28 & -0.05 & -0.06 & 0.15 & 0.08 & 0.02 & 0.29 & 0.18 \\
\hline 13. Overseas Market Age & $0.15^{*}$ & $0.20 *$ & $0.22 * *$ & 0.11 & -0.01 & $0.12 *$ & 0.10 & 0.11 & 0.07 & $0.30 *$ & $0.67 * *$ & $0 . \overline{45} * *$ & $\underline{\mathbf{N A}}$ & 0.14 & -0.12 & 0.07 & 0.14 & 0.11 & -0.02 & 0.08 & 0.40 \\
\hline 14. Mutual RSI & $0.35 * *$ & $0.34 * *$ & $0.39 * *$ & 0.11 & -0.09 & $0.43 * *$ & $0.24 * *$ & $0.19 * *$ & $0.21 * *$ & 0.08 & $0.18^{* *}$ & $0.29 * *$ & $\overline{0.15} *$ & $\underline{\text { NA }}$ & -0.03 & -0.02 & 0.00 & 0.26 & 0.29 & 0.12 & 0.04 \\
\hline 15. Customer's Value Proposition & 0.06 & 0.09 & 0.08 & 0.03 & 0.04 & 0.01 & 0.11 & 0.08 & 0.11 & -0.01 & -0.05 & -0.04 & -0.11 & -0.02 & NA & 0.02 & 0.05 & 0.09 & 0.01 & -0.08 & 0.06 \\
\hline 16. R\&D Expenditure & -0.01 & 0.03 & 0.03 & 0.08 & 0.03 & -0.03 & 0.10 & 0.04 & 0.03 & $0.13^{*}$ & 0.10 & -0.05 & 0.08 & -0.01 & $\overline{0.03}$ & $\underline{\text { NA }}$ & 0.09 & -0.07 & -0.14 & 0.00 & 0.06 \\
\hline 17. Number of NPD & $0.12 *$ & $0.16 * *$ & $0.14 *$ & 0.09 & -0.01 & $0.14 *$ & $0.22 * *$ & $0.14 *$ & $0.18 * *$ & $0.12 *$ & $0.16^{*}$ & $0.16^{* *}$ & $0.15^{*}$ & 0.01 & 0.06 & $\overline{0.10}$ & $\underline{\text { NA }}$ & 0.16 & -0.02 & 0.11 & 0.12 \\
\hline 18. Joint Innovation Activities & $0.38 * *$ & $0.35 * *$ & $0.42 * *$ & $0.31 * *$ & 0.03 & $0.30 * *$ & $0.29 * *$ & $0.29 * *$ & $0.29 * *$ & $0.12 *$ & 0.09 & 0.09 & 0.12 & $0.27 * *$ & 0.10 & -0.06 & $\overline{0.17} * *$ & NA & 0.30 & 0.20 & 0.14 \\
\hline 19. Market Conditions & $0.26 * *$ & $0.21 * *$ & $0.27 * *$ & 0.09 & 0.02 & $0.22 * *$ & $0.19^{* *}$ & $0.16^{* *}$ & $0.23 * *$ & 0.06 & -0.08 & 0.03 & -0.01 & 0.30 ** & 0.02 & $-0.13 *$ & -0.01 & $0.31 * *$ & NA & 0.16 & -0.10 \\
\hline 20. Customer's Global Reach & $0.19 * *$ & $0.23 * *$ & $0.20^{* *}$ & 0.01 & $0.30 * *$ & $0.16^{* *}$ & $0.19 * *$ & $0.18^{* *}$ & $0.20 * *$ & $0.23 * *$ & 0.01 & $0.30 * *$ & 0.09 & $0.13 *$ & -0.07 & 0.01 & $0.12 *$ & $0.21 * *$ & $\overline{0.17} * *$ & NA & -0.19 \\
\hline 21. Respondent's Tenure & 0.06 & 0.06 & 0.10 & 0.05 & -0.02 & 0.10 & 0.07 & 0.05 & 0.04 & 0.01 & $0.58 * *$ & $0.19 * *$ & $0.41 * *$ & 0.05 & 0.07 & 0.07 & $0.13 *$ & $0.15^{*}$ & -0.09 & $-0.18 * *$ & NA \\
\hline 22. Marker Variable (MV) & 0.07 & 0.08 & 0.07 & -0.03 & 0.07 & 0.05 & 0.06 & $0.14 *$ & 0.04 & 0.04 & 0.01 & 0.02 & $-0.13^{*}$ & $0.14 *$ & 0.10 & -0.08 & -0.04 & -0.01 & $0.18 * *$ & -0.07 & $\overline{-0.01}$ \\
\hline Mean & 5.56 & 5.75 & 5.71 & 5.01 & 3.34 & 5.30 & 5.43 & 5.37 & 5.57 & 5.41 & 1.16 & 0.70 & 9.07 & 5.43 & 5.90 & 30.67 & 4.47 & 5.91 & 5.52 & 2.24 & 9.28 \\
\hline Standard deviation & 0.73 & 0.75 & 0.67 & 1.11 & 1.06 & 0.99 & 0.81 & 0.91 & 0.87 & 1.27 & 0.22 & 0.23 & 5.12 & 1.25 & 0.95 & 78.26 & 2.36 & 0.90 & 1.05 & 0.76 & 4.82 \\
\hline
\end{tabular}

Note:

Correlations below the diagonal are before the MV adjustment.

Correlations above the diagonal are after the MV adjustment.

Correlations above 0.12 are significant at $p<0.05$.

Bold and underlined numbers on the diagonal show the square root of the AVEs

$\mathrm{n}=264$

$* * p<0.01, * p<0.05$ 
Table 4: Results of regression test for self-selection bias

\begin{tabular}{llll} 
& $\begin{array}{l}\text { Model1 } \\
\text { (includes correction term) }\end{array}$ & $\begin{array}{l}\text { Model2 } \\
\text { (Exclude correction term) }\end{array}$ \\
\cline { 2 - 2 } RL & $0.30 * *$ & $0.27^{* *}$ \\
CDep & -0.05 & -0.06 \\
CDis & -0.09 & -0.10 \\
RL $x$ CDis & $-0.21^{* *}$ & $-0.21^{* *}$ \\
RL $x$ CDep & $0.14^{*}$ & $0.13^{*}$ \\
\hline $\mathrm{R}^{2}$ & 0.20 & 0.19
\end{tabular}

RL: relationship learning; CDep: customer dependence; CDist: cultural distance; $\mathrm{n}=264$

$* * p<0.01, * p<0.05$ 
Table 5: Results of structural equations analyses

\begin{tabular}{|c|c|c|c|c|c|c|c|c|c|}
\hline Structural Model Statistics & \multicolumn{4}{|c|}{ Full Mediation Model } & \multicolumn{5}{|c|}{ Partial Mediation Model } \\
\hline $\mathrm{X}^{2}$ & 488.93 & & & & 467.39 & & & & \\
\hline d.f. & 322 & & & & 321 & & & & \\
\hline CFI & 0.92 & & & & 0.93 & & & & \\
\hline TLI & 0.90 & & & & 0.91 & & & & \\
\hline RMSEA & 0.05 & & & & 0.05 & & & & \\
\hline \multirow[b]{2}{*}{ Path } & \multirow{2}{*}{$\begin{array}{l}\text { Path } \\
\text { Estimate }\end{array}$} & \multirow[b]{2}{*}{ S.E. } & \multicolumn{2}{|c|}{$95 \% \mathrm{CI}$} & \multirow{2}{*}{$\begin{array}{l}\text { Path } \\
\text { Estimate }\end{array}$} & \multirow[b]{2}{*}{ S.E. } & \multicolumn{2}{|c|}{$95 \% \mathrm{CI}$} & \\
\hline & & & Lower & Upper & & & Lower & Upper & \\
\hline \multicolumn{10}{|l|}{ Main effects } \\
\hline $\mathrm{RL} \rightarrow \mathrm{SP}$ & -- & -- & -- & -- & $0.38 * *$ & 0.12 & 0.26 & 0.58 & \\
\hline $\mathrm{RL} \rightarrow \mathrm{ICInv}$ & $0.36^{* *}$ & 0.14 & 0.22 & 0.47 & $0.35 * *$ & 0.14 & 0.22 & 0.46 & \\
\hline $\mathrm{ICInv} \rightarrow \mathrm{SP}$ & $0.24 * *$ & 0.05 & 0.11 & 0.37 & $0.15 *$ & 0.04 & 0.02 & 0.29 & H1 Accepted \\
\hline \multicolumn{10}{|l|}{ Interactions } \\
\hline RL $x$ CDist $\rightarrow$ ICInv & $-0.18 * *$ & 0.10 & -0.30 & -0.05 & $-0.18 * *$ & 0.10 & -0.30 & -0.05 & H2 Accepted \\
\hline ICInv x CDist $\rightarrow$ SP & $-0.22 * *$ & 0.03 & -0.35 & -0.09 & $-0.19 * *$ & 0.03 & -0.32 & -0.07 & H3 Accepted \\
\hline RL x CDep $\rightarrow$ ICInv & $0.14^{*}$ & 0.09 & 0.01 & 0.26 & $0.14 *$ & 0.09 & 0.01 & 0.26 & H4 Accepted \\
\hline ICInv x CDep $\rightarrow$ SP & 0.02 & 0.03 & -0.11 & 0.14 & -0.02 & 0.03 & -0.15 & 0.11 & H5 Rejected \\
\hline \multicolumn{10}{|l|}{ Controls } \\
\hline Supplier Size & -0.02 & 0.04 & -0.14 & 0.12 & -0.02 & 0.04 & -0.14 & 0.11 & \\
\hline Supplier Age & -0.04 & 0.30 & -0.22 & 0.14 & -0.10 & 0.28 & -0.28 & 0.07 & \\
\hline Relationship Age & 0.11 & 0.22 & -0.02 & 0.25 & 0.11 & 0.21 & -0.02 & 0.26 & \\
\hline Overseas Market Age & -0.02 & 0.01 & -0.18 & 0.15 & -0.03 & 0.01 & -0.19 & 0.12 & \\
\hline Mutual RSI & $0.14 *$ & 0.04 & 0.02 & 0.27 & 0.03 & 0.04 & -0.10 & 0.18 & \\
\hline Customer's Value Proposition & 0.09 & 0.04 & -0.03 & 0.20 & 0.07 & 0.04 & -0.05 & 0.17 & \\
\hline R\&D Expenditure & 0.08 & 0.00 & -0.05 & 0.19 & 0.08 & 0.00 & -0.05 & 0.18 & \\
\hline Number of NPD & $0.13 *$ & 0.02 & 0.02 & 0.25 & $0.12 *$ & 0.02 & 0.00 & 0.23 & \\
\hline Joint Innovation Activities & $0.13 *$ & 0.05 & 0.02 & 0.30 & 0.05 & 0.05 & -0.08 & 0.20 & \\
\hline Market Conditions & 0.11 & 0.04 & -0.02 & 0.23 & 0.06 & 0.04 & -0.05 & 0.19 & \\
\hline Customer's Global Reach & 0.08 & 0.06 & -0.06 & 0.23 & 0.05 & 0.06 & -0.10 & 0.18 & \\
\hline Respondent's Tenure & 0.02 & 0.01 & -0.13 & 0.17 & 0.06 & 0.01 & -0.09 & 0.19 & \\
\hline Marker Variable (MV) & 0.05 & 0.04 & -0.07 & 0.17 & 0.05 & 0.04 & -0.07 & 0.17 & \\
\hline
\end{tabular}

Note:

RL: relationship learning; ICInv: international customer involvement in the design stage; SP: supplier performance; CDist: cultural distance; CDep: customer dependence

S.E.: Standard Error; CI: Confidence Interval; $\mathrm{n}=264$

$* * p<0.01, * p<0.05$ 
Figure 1: Conceptual Model

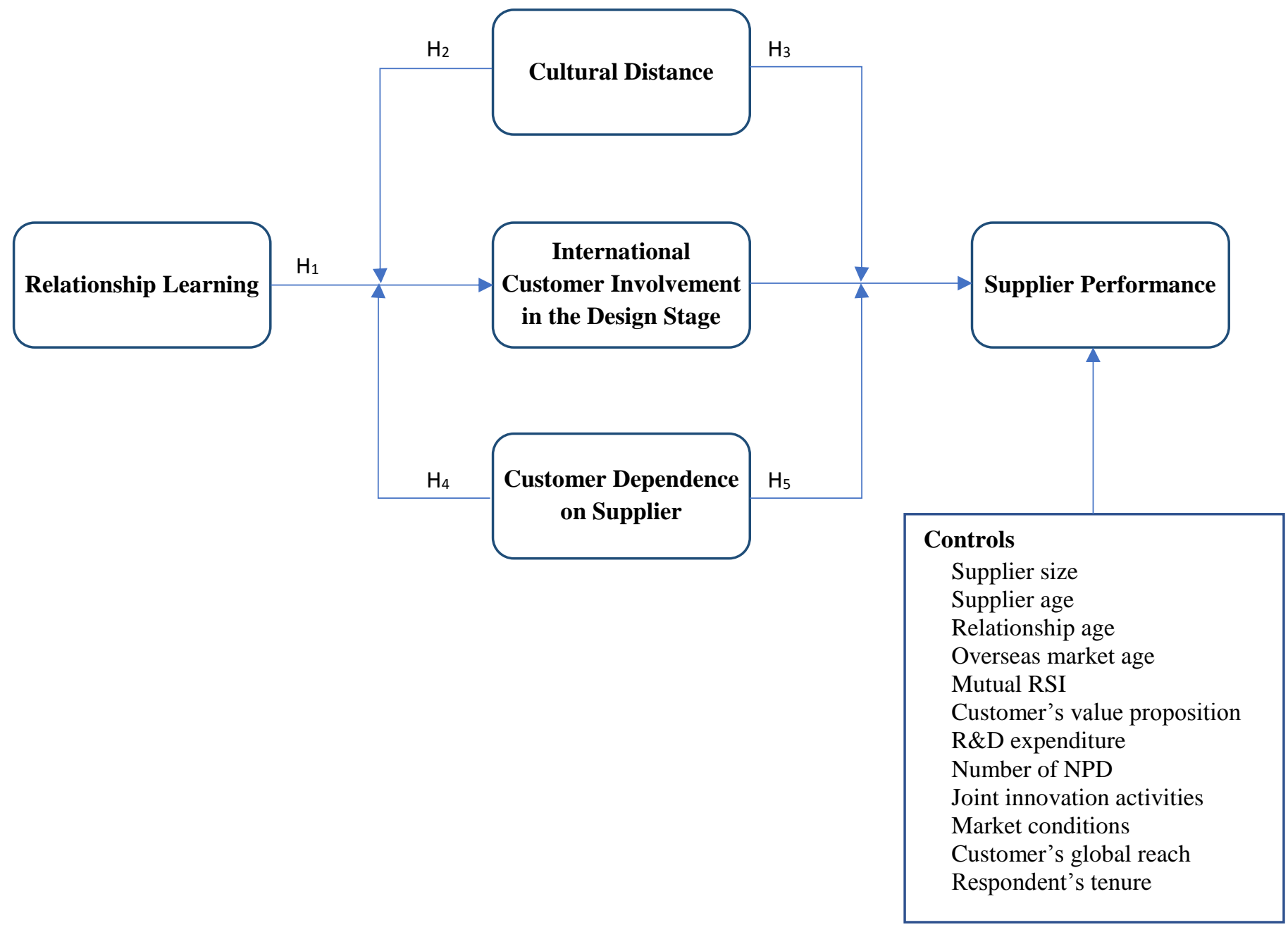




\section{Appendix 1: Measurement Items and Model Results}

\begin{tabular}{|c|c|}
\hline Constructs and items & $\begin{array}{l}\text { Standardized } \\
\text { loading }\end{array}$ \\
\hline \multicolumn{2}{|l|}{$\begin{array}{l}\text { Relationship learning }- \text { adapted from Selnes and Sallis, } 2003 \\
\text { (Likert Scales: } 1=\text { strongly disagree, } 7=\text { strongly agree) }\end{array}$} \\
\hline \multicolumn{2}{|l|}{ - Information sharing $(\alpha=0.88, C R=0.88, A V E=0.52)$} \\
\hline $\begin{array}{l}\text { Our two firms exchange information on successful and unsuccessful experiences with products exchanged in the } \\
\text { relationship. }\end{array}$ & 0.77 \\
\hline Our two firms exchange information related to changes in end-user needs, preferences, and behavior. & 0.70 \\
\hline Our two firms exchange information related to changes in market structure, such as mergers, acquisitions, or partnering. & 0.66 \\
\hline Our two firms exchange information related to changes in the technology of the focal products. & 0.70 \\
\hline Our two firms exchange information as soon as any unexpected problems arise. & 0.73 \\
\hline Our two firms exchange information related to changes in the two organizations' strategies and policies. & 0.78 \\
\hline $\begin{array}{l}\text { Our two firms exchange information that is sensitive for both parties, such as financial performance and company know- } \\
\text { how. }\end{array}$ & 0.70 \\
\hline \multicolumn{2}{|l|}{ - Joint sensemaking $(\alpha=0.84, C R=0.83, A V E=0.54)$} \\
\hline It is common to establish joint teams to solve operational problems in the relationship. & 0.75 \\
\hline It is common to establish joint teams to analyze and discuss strategic issues. & 0.76 \\
\hline The atmosphere in the relationship stimulates productive discussion that encompasses a variety of opinions. & 0.73 \\
\hline We have a lot of face-to-face communication in this relationship. & 0.71 \\
\hline \multicolumn{2}{|l|}{ - Knowledge integration $(\alpha=0.86, C R=0.86, A V E=0.52)$} \\
\hline Our two firms frequently adjust our common understanding of end-user needs and behavior. & 0.71 \\
\hline Our two firms frequently adjust our common understanding of trends in technology related to our business. & 0.76 \\
\hline Our two firms frequently evaluate and, if needed, adjust our routines in order-delivery processes. & 0.65 \\
\hline Our two firms frequently evaluate and, if needed, update the formal contracts in our relationship. & 0.69 \\
\hline Our two firms frequently meet face-to-face to refresh the personal network in this relationship. & 0.72 \\
\hline $\begin{array}{l}\text { Our two firms frequently evaluate and, if needed, update information about the relationship stored in our electronic } \\
\text { databases. }\end{array}$ & 0.78 \\
\hline \multicolumn{2}{|l|}{$\begin{array}{l}\text { International customer involvement in the design stage ( } \boldsymbol{\alpha}=\mathbf{0 . 8 6}, \boldsymbol{C R}=\mathbf{0 . 8 6}, \boldsymbol{A V E}=\mathbf{0 . 6 2}) \text { - adapted from Menguc et al., } 2014 . \\
\text { What is the frequency with which these practices are used to verify that the design meets customer requirements? } \\
\text { (Likert Scales: } 1=\text { never }-0 \% \text { of the time; } 7=\text { always } 100 \% \text { of the time) }\end{array}$} \\
\hline Cross-functional design teams with customers & 0.66 \\
\hline Design reviews by customers & 0.83 \\
\hline Design review teams with customer representatives & 0.84 \\
\hline Customer pilot runs & 0.80 \\
\hline \multicolumn{2}{|l|}{$\begin{array}{l}\text { Customer's dependence on supplier }(\boldsymbol{\alpha}=\mathbf{0 . 8 2}, \boldsymbol{C R}=\mathbf{0 . 8 2 ,} \boldsymbol{A V E}=\mathbf{0 . 6 1}) \text { - adapted from Fang et al., } 2008 \\
\text { (Likert Scales: } 1=\text { strongly disagree, } 7=\text { strongly agree) }\end{array}$} \\
\hline It would be difficult for this international customer to replace us. & 0.71 \\
\hline This international customer is quite dependent on us. & 0.81 \\
\hline If this relationship ended, this international customer would face a significant loss. & 0.82 \\
\hline \multicolumn{2}{|l|}{$\begin{array}{l}\text { Supplier performance }- \text { adapted from Katsikeas et al., } 2006 \\
\text { (Likert Scales: } 1=\text { Much worse, } 7=\text { Much better) }\end{array}$} \\
\hline \multicolumn{2}{|l|}{ - Sales performance $(\alpha=0.79, C R=0.79, A V E=0.56)$} \\
\hline Sales volume & 0.74 \\
\hline Sales growth & 0.75 \\
\hline New product sales & 0.75 \\
\hline \multicolumn{2}{|l|}{ - Financial performance $(\alpha=0.84, C R=0.84, A V E=0.64)$} \\
\hline Profitability as a percentage of sales & 0.80 \\
\hline Return on investment & 0.82 \\
\hline Profit growth & 0.78 \\
\hline \multicolumn{2}{|l|}{ - Customer performance $(\alpha=0.82, C R=0.82, A V E=0.60)$} \\
\hline Customer satisfaction & 0.72 \\
\hline Customer retention & 0.75 \\
\hline Customer referral & 0.85 \\
\hline
\end{tabular}

Note:

All loadings are significant at $p<0.01$,

Fit statistics: $\mathrm{X}_{(d f=467)}=721.03$; RMSEA= 0.04; CFI= 0.95; TLI= 0.94; IFI= 0.95 . 